\title{
MUSHROOM DIVERSITY OF KONKAN REGION OF MAHARASHTRA, INDIA
}

\section{Pramod Borkar ${ }^{1}$, Anila Doshi ${ }^{2} \&$ Sudhir Navathe ${ }^{3}$}

${ }^{1,3}$ Department of Plant Pathology, Dr. B.S. Konkan Krishi Vidyapeeth (Agricultural University), Dapoli, Maharashtra 415712, India

${ }^{2}$ Maharana Pratap University of Agriculture and Technology, Udaipur, Rajasthan 313001, India

${ }^{1}$ pramodgb@gmail.com (corresponding author), ${ }^{2}$ anila_doshi@yahoo.co.in, ${ }^{3}$ sudhir.agro123@gmail.com

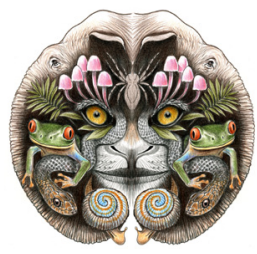

ISSN 0974-7907 (Online) ISSN 0974-7893 (Print)

OPEN ACCESS

Abstract: The forays conducted in the diverse habitats of the Konkan region of Maharashtra for four consecutive monsoon seasons during 2008-2012, revealed the occurrence of 29 mushrooms. Among the collected mushrooms, six belonged to the family Agaricaceae, five to Lyophyllaceae, two each to Pleurotaceae, Hygrophoraceae, Marasmiaceae and Tricholomataceae; one each to Phallaceae, Physalacriaceae, Xylariaceae, Tremellaceae, Sclerodermataceae, Decrymycetaceae, Cantharellaceae, Entolomaceae, Plutaceae and Ganodermataceae. The morphology of Tremella, Dictyophora, Daldinia, Pisolithus and Calocera were quite distinct and interesting.

Keywords: Agariaceae, Lyophyllaceae, macrofungi, morpho-taxonomy, mushroom diversity, Western Ghats.
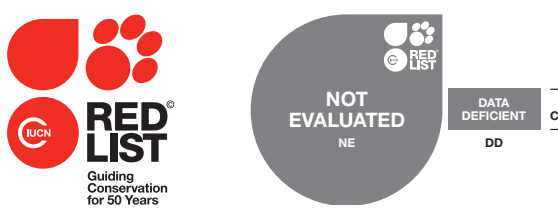

Hygrocybe miniato
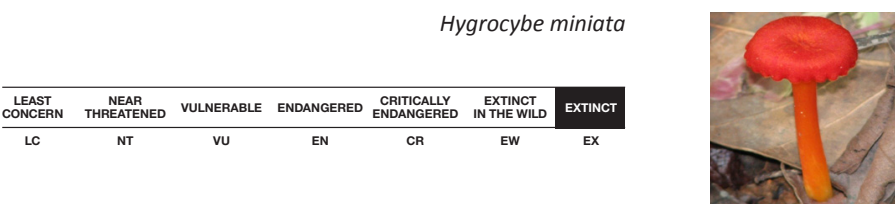

DOI: http://dx.doi.org/10.11609/JoTT.04283.7625-40

Editor: R.K. Verma, Tropical Forest Research Institute, Jabalpur, India.

Date of publication: 26 August 2015 (online \& print)

Manuscript details: Ms \# 04283 | Received 08 December 2014 | Final received 13 July 2015 | Finally accepted 30 July 2015

Citation: Borkar, P., A. Doshi \& S. Navathe (2015). Mushroom diversity of Konkan region of Maharashtra, India. Journal of Threatened Taxa 7(10): 7625-7640; http://dx.doi.org/10.11609/JoTT.04283.7625-40

Copyright: (c) Borkar et al. et al. 2015. Creative Commons Attribution 4.0 International License. JoTT allows unrestricted use of this article in any medium, reproduction and distribution by providing adequate credit to the authors and the source of publication.

Funding: None.

Competing interests: The authors declare no competing interests.

Author Details: Pramod Borkar Assistant Professor, his basic research area is mushroom diversity, domestication of edible mushroom species, Diseases of planation and horticultural crops. He is active member of Mushroom society of India, Indian Mycological society, Indian phytopathological society. He is active in extension work of various cultivation technologies edible mushroom, management of disease, integrated disease management technologies. DR. ANILA DosHI Professor and Head, has worked as Mycologist; All India coordinated Research Project on Mushrooms for more than two decades. During this period she identified and documented about 200 wild mushrooms from Rajasthan. She was awarded the Best Teacher Award by MPUAT. She is active member of Mushroom society of India, and Indian Society of Mycology and Plant Pathology. SUDHIR NAVATHE B.Sc. in agriculture and M.Sc. plant pathology, is awarded with Hexamer Gold medal in plant pathology by Dr. Balasaheb Sawant Konkan Krishi Vidyapeeth and INSPIRE RESEACH FELLOWSHIP 2014-15 by Deparment of Science and Technology, Govt. of India. He started his research career with research in cultivation technology of milky white mushroom and oyster mushrooms with innovative techniques, and mushroom biodiversity; further working on various aspects in phytopathology and molecular plant pathology.

Author Contribution: PB and SN contributed in surveying, collection, identification and microscopic characterization of mushrooms and preparation of manuscript. $A D$ contributed to the specific identification of mushrooms, confirming the names of mushrooms and guidance during this research work.

Acknowledgements: Authors are thankful to the Department of Plant Pathology Dr. Balasaheb Sawant Konkan Krishi Vidyapeeth (Agricultural University) Dapoli, Maharashtra; Department of Plant Pathology, Maharana Pratap University of Agriculture and Technology, Udaipur Rajasthan necessary for research facility and database.
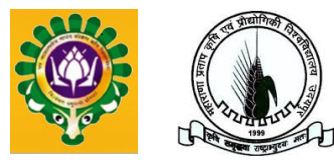


\section{INTRODUCTION}

The macrofungal diversity is depleting fast due to deforestation, urbanization, climate change and unsystematic exploitation through collection of wild mushrooms. This situation demands an urgent need to collect, document and conserve this group. Most macrofungi are cosmopolitan, occurring both in tropical and temperate regions. They occur seasonally all over the world in various habitats such as humus rich soils, decaying plant litter and wood logs in forests as well as in meadows and even in sandy and other soils. Some species, particularly mycorrhizal mushrooms are on the verge of extinction.

India, being one of the top 10 mega diverse nations of the world, has ample species of wild mushrooms which occur mainly during the rainy season. The diversity of geographical, ecological and climatic conditions prevailing in India has made this country a natural habitat for a large number of fungal species. Six regions, viz., Eastern Himalayan, northwest Himalayan, Indo Gangetic Plain, Western Ghats, southern India and Rajasthan have been explored by a number of workers throughout the country as hot spots of mushroom diversity, since 1825 .

The work on collection and taxonomic studies of mushrooms in Maharashtra started as late as 1974. Prof. A.V. Sathe and his team recorded 75 species distributed in 43 genera from the collections made from the states of Maharashtra, Karnataka and Kerala during 1978-1980. This collection was documented in the form of a monograph on Agaricales. As far as the collection of macrofungi from Maharashtra is concerned, mostly it remained confined to western Maharashtra. Very few mushrooms viz., Fistulina hepatica, Entyloma achrospora, E. strictus, Rhodophyllus achrosporus and $R$. overeemi were recorded from the Konkan region, is a narrow strip of $720 \mathrm{~km}$ comprising four districts, viz.: Thane, Raigad, Ratnagiri and Sindhudurg. On the eastern side of the region lies the Sahyadri mountain range which is a part of the Western Ghats. The Sahyadri mountain range is bestowed with rich flora and fauna.

\section{MATERIALS AND METHODS}

Mushrooms from four districts of Konkan region viz., Thane, Raigad, Ratnagiri and Sindhudurg were collected for four consecutive monsoon seasons in the years from 2008 to 2012. Selected spots included Amboli, an area with well-known high altitude biodiversity, sea shore area like Murud, horticultural plantations with mango, cashew, coconut and arecanut at Wakavali, Kelshi, Inampangari, lateritic soil vegetation in Sindhudurg District comprising places like Kudal, Malvan, Pandur, Koloshi and Kanakvali and black soil area such as Wada and Palghar in Thane District and thick forest areas in Rajapur, Lanja, Sangameshwar, Ratnagiri, Chiplun and Dapoli tahasils. Identification of the collected mushroom specimens was done on the basis of their macroscopic (morphological) and microscopic characters. For recording field observations, a pro-forma was prepared (as per George Mimes "Principles of Mushroom Identification) (Tibuhwa et al. 2010). At the time of collection of mushrooms, date of collection, locality and habitat were recorded. Every specimen was recorded with a collection number. Descriptions are based on fresh collections made from Konkan regions. Microscopic observations were made from free hand sections mounted in lectophenol cotton blue. All collections studied are deposited at the Mycological Herbarium of Department of Plant Pathology, Dr. B.S. Konkan Krishi Vidyapeeth Dapoli, Ratnagiri, Maharashtra, India.

\section{RESULTS}

Twenty-nine mushrooms from different families were collected during these surveys (Table 1; Images 1-19).

The mushrooms collected from different locations in Konkan region (Appendix 1 and 2) include: Agaricu splacomyces, Lepiota spp., Pleurotus spp., Marasmius haematocephalus, Lepista nuda, Tremella fuciformis, Pisolithus tinctorius, Armillaria tebescens and Calocera cornea. Termitomyces heimii, T. microcarpus, Leucocoprinus birnbaumii, Pleurotus pulmonarius, Dictyophora duplicata and Entoloma roseoflavum.

The mushrooms, viz., Agaricustri sulphuratus, Daldinia concentrica and Pleutus cervinus, were found to occur only in Ratnagiri District and all the collected mushrooms occur in Ratnagiri District. The morphological description of these mushrooms is as follows:

\section{Armillaria tabescens (Scop.) Emel. (Physalacriaceae) (Image 1)}

Synnonym: Clitocybe tabescens (Scop.) Bres

Habitat: Growing on bamboo roots, cespitose clusters

Pileus: Bright yellow ochraceous brown in age, $6 \mathrm{~cm}$ in diameter, glabrous, convex to shield shaped with entire to undulate margin.

Stipe: Equal, eccentric, concolorous with pileus 
Table 1. Occurrence of naturally growing mushroom flora in four districts of Konkan

\begin{tabular}{|c|c|c|c|c|c|c|c|c|c|c|c|c|c|c|c|c|c|c|c|c|c|}
\hline & \multirow{2}{*}{ Scientific name } & \multicolumn{4}{|c|}{2008} & \multicolumn{4}{|c|}{2009} & \multicolumn{4}{|c|}{2010} & \multicolumn{4}{|c|}{2011} & \multicolumn{4}{|c|}{2012} \\
\hline & & $\mathrm{Si}$ & Rt & Rg & Th & Si & Rt & $\mathbf{R g}$ & Th & $\mathrm{Si}$ & Rt & Rg & Th & $\mathrm{Si}$ & Rt & Rg & Th & $\mathrm{Si}$ & Rt & $\mathrm{Rg}$ & Th \\
\hline 1 & Armillaria tabescens & 0 & 0 & - & 0 & $\mathrm{O}$ & 0 & - & 0 & $\mathrm{O}$ & $\mathrm{O}$ & - & 0 & $\mathrm{O}$ & $\mathrm{O}$ & - & 0 & 0 & $\mathrm{O}$ & 0 & $\mathrm{O}$ \\
\hline 2 & Agaricus arvensis & - & - & - & - & - & $\mathrm{O}$ & 0 & 0 & $\mathrm{O}$ & $\mathrm{O}$ & $\mathrm{O}$ & 0 & - & $\mathrm{O}$ & $\mathrm{O}$ & $\mathrm{O}$ & 0 & $\mathrm{O}$ & - & - \\
\hline 3 & Agaricus placomyces & $\mathrm{O}$ & 0 & 0 & - & $\mathrm{O}$ & $\mathrm{O}$ & 0 & - & $\mathrm{O}$ & $\mathrm{O}$ & $\mathrm{O}$ & - & $\mathrm{O}$ & 0 & $\mathrm{O}$ & - & - & - & - & - \\
\hline 4 & Agaricus trisulphuratus & - & 0 & - & - & - & 0 & - & - & - & $\mathrm{O}$ & - & - & - & 0 & - & - & $\mathrm{o}$ & $\mathrm{o}$ & - & - \\
\hline 5 & Calocera cornea & - & 0 & - & - & $\mathrm{O}$ & $\mathrm{O}$ & - & - & $\mathrm{O}$ & $\mathrm{O}$ & - & $\mathrm{O}$ & $\mathrm{O}$ & 0 & $\mathrm{O}$ & - & 0 & 0 & - & 0 \\
\hline 6 & Clitocybe spp. & - & - & - & - & $\mathrm{O}$ & $\mathrm{O}$ & $\mathrm{o}$ & 0 & $\mathrm{O}$ & $\mathrm{O}$ & $\mathrm{O}$ & $\mathrm{O}$ & $\mathrm{O}$ & 0 & $\mathrm{O}$ & 0 & - & $\mathrm{O}$ & - & - \\
\hline 7 & Creterellus tubaeformis & - & 0 & - & - & 0 & $\mathrm{O}$ & 0 & 0 & $\mathrm{O}$ & $\mathrm{O}$ & - & - & - & - & - & - & - & $\mathrm{O}$ & 0 & - \\
\hline 8 & Daldinia concentrica & - & - & - & - & - & - & - & - & & 0 & - & 0 & 0 & 0 & - & 0 & 0 & - & - & - \\
\hline 9 & Dyctiophora duplicate & 0 & 0 & - & - & $\mathrm{O}$ & $\mathrm{O}$ & - & - & $\mathrm{O}$ & 0 & - & - & 0 & 0 & - & - & 0 & 0 & - & - \\
\hline 10 & Enoloma roseoflavum & - & $\mathrm{O}$ & - & - & $\mathrm{O}$ & $\mathrm{O}$ & - & - & $\mathrm{O}$ & $\mathrm{O}$ & - & - & $\mathrm{O}$ & 0 & - & - & $\mathrm{o}$ & $\mathrm{o}$ & - & - \\
\hline 11 & Ganoderma lucidum & $\mathrm{O}$ & $\mathrm{O}$ & 0 & 0 & 0 & $\mathrm{O}$ & $\mathrm{O}$ & 0 & $\mathrm{O}$ & $\mathrm{O}$ & $\mathrm{O}$ & $\mathrm{O}$ & $\mathrm{O}$ & $\mathrm{O}$ & - & - & 0 & $\mathrm{o}$ & 0 & - \\
\hline 12 & Hygrocybe Conica & - & 0 & - & - & 0 & $\mathrm{O}$ & 0 & 0 & $\mathrm{O}$ & $\mathrm{O}$ & - & - & $\mathrm{O}$ & 0 & 0 & 0 & 0 & $\mathrm{O}$ & - & 0 \\
\hline 13 & Hygrocybe miniata & 0 & $\mathrm{O}$ & 0 & 0 & 0 & $\mathrm{O}$ & $\mathrm{O}$ & 0 & $\mathrm{O}$ & 0 & $\mathrm{O}$ & 0 & 0 & 0 & 0 & 0 & 0 & $\mathrm{O}$ & 0 & 0 \\
\hline 14 & Lepiota spp. & - & 0 & - & - & 0 & $\mathrm{O}$ & - & - & $\mathrm{O}$ & 0 & - & 0 & 0 & 0 & - & - & 0 & 0 & - & 0 \\
\hline 15 & Lepista nuda & - & - & - & - & 0 & $\mathrm{O}$ & - & 0 & $\mathrm{O}$ & 0 & - & 0 & 0 & 0 & - & 0 & 0 & 0 & 0 & - \\
\hline 16 & Leucocoprinus birnbaumii & - & - & - & $\mathrm{O}$ & - & - & - & - & - & - & - & - & - & - & - & - & 0 & 0 & 0 & $\mathrm{O}$ \\
\hline 17 & Macrolepiota procera & - & - & - & - & 0 & $\mathrm{O}$ & $\mathrm{O}$ & 0 & $\mathrm{O}$ & 0 & 0 & 0 & 0 & $\mathrm{O}$ & 0 & 0 & 0 & 0 & 0 & $\mathrm{O}$ \\
\hline 18 & Maramiallus ramealis & - & - & - & - & $\mathrm{O}$ & $\mathrm{O}$ & 0 & 0 & $\mathrm{O}$ & 0 & $\mathrm{O}$ & 0 & 0 & 0 & 0 & 0 & - & $\mathrm{O}$ & 0 & $\mathrm{O}$ \\
\hline 19 & Marasmus haematocephlous & 0 & 0 & - & $\mathrm{O}$ & $\mathrm{O}$ & $\mathrm{O}$ & - & 0 & $\mathrm{O}$ & 0 & - & 0 & 0 & 0 & - & 0 & 0 & 0 & 0 & 0 \\
\hline 20 & Pisolithus tinctorius & 0 & 0 & - & - & 0 & $\mathrm{O}$ & 0 & - & $\mathrm{O}$ & 0 & 0 & - & 0 & 0 & 0 & - & 0 & $\mathrm{O}$ & - & - \\
\hline 21 & Pleurotus ostreatus & - & - & - & - & $\mathrm{O}$ & $\mathrm{O}$ & - & 0 & $\mathrm{O}$ & $\mathrm{O}$ & - & 0 & 0 & 0 & - & 0 & 0 & 0 & 0 & 0 \\
\hline 22 & Pleurotus pulmonarius & - & - & - & - & 0 & 0 & $\mathrm{O}$ & 0 & $\mathrm{O}$ & $\mathrm{O}$ & 0 & $\mathrm{O}$ & $\mathrm{O}$ & 0 & 0 & 0 & 0 & 0 & & 0 \\
\hline 23 & Pluteus cervinus & - & - & - & - & - & $\mathrm{O}$ & - & - & - & 0 & - & - & 0 & 0 & - & $\mathrm{O}$ & 0 & 0 & - & $\mathrm{O}$ \\
\hline 24 & Termitomyces clypeatus & - & - & - & - & $\mathrm{O}$ & $\mathrm{O}$ & 0 & 0 & $\mathrm{O}$ & $\mathrm{O}$ & $\mathrm{O}$ & $\mathrm{O}$ & 0 & 0 & 0 & 0 & 0 & 0 & 0 & 0 \\
\hline 25 & Termitomyces heimii & 0 & 0 & 0 & 0 & 0 & $\mathrm{O}$ & 0 & 0 & $\mathrm{O}$ & $\mathrm{O}$ & 0 & 0 & $\mathrm{O}$ & 0 & 0 & 0 & - & 0 & 0 & 0 \\
\hline 26 & Termitomyces logiradicata & - & - & - & - & 0 & $\mathrm{O}$ & - & - & $\mathrm{O}$ & $\mathrm{O}$ & - & - & 0 & 0 & - & - & - & 0 & - & - \\
\hline 27 & Termitomyces microcarpus & - & - & - & - & 0 & 0 & - & - & $\mathrm{O}$ & 0 & - & - & $\mathrm{O}$ & 0 & - & - & $\mathrm{o}$ & 0 & 0 & - \\
\hline 28 & Termitomyces umkowaani & - & - & - & - & 0 & $\mathrm{O}$ & - & 0 & $\mathrm{O}$ & $\mathrm{O}$ & - & 0 & 0 & 0 & - & 0 & 0 & 0 & 0 & 0 \\
\hline 29 & Tremella fuciformis & $\mathrm{O}$ & $\mathrm{O}$ & $\mathrm{O}$ & 0 & 0 & 0 & $\mathrm{O}$ & 0 & $\mathrm{O}$ & $\mathrm{O}$ & 0 & $\mathrm{O}$ & 0 & 0 & 0 & 0 & 0 & 0 & 0 & 0 \\
\hline
\end{tabular}

Si - Sindhudurg; Rt - Ratnagiri; Rg - Raigad; Th - Thane; O - Observed; - Not observed

fibrous and hollow in the centre; $5.5 \mathrm{~cm}$ length and $2 \mathrm{~cm}$ in width.

Lamellae: Yellow then dicoloured, close, adnate. Spore print was white, annulus and volva not observed.

Microscopic features: Spores hyaline, globose, thin walled and measured $5 \mu \mathrm{m}$. Basidia measured $10 \times 2.50$ $\mu \mathrm{m}$, cystidia measured $17.50 \times 5 \mu \mathrm{m}$.

\section{Agaricus arvensis Schaeff (Agaricaceae) (Image 2)}

Habitat: Growing in decaying plant litter of perennials.

Pileus: Fleshy, 15-16 cm in diameter, buff brown with brown spot in centre, glabrous, convex in shape becoming plano-convex in age with entire margin.
Stipe: Concolorous with pileus, equal, slightly swollen at the base, fibrous, fleshy in texture, measuring: 10-12 $\mathrm{cm}$ in length and $2-3 \mathrm{~cm}$ in width.

Lamellae: Crowded, free, light brown initially, becoming pinkish in age. Spore print dark brown. Annulus present, persisting like frill; volva absent.

Microscopic features: Spores dark brown, oval to ellipsoid, thin walled measuring 7x2.5 $\mu \mathrm{m}$. Basidia measured $12.5 \times 5 \mu \mathrm{m}$ while cystidia not observed.

\section{Agaricus placomyces Peck. (Agaricaceae)}

Habitat: Solitary or in cespitose clusters, in plant debris. 


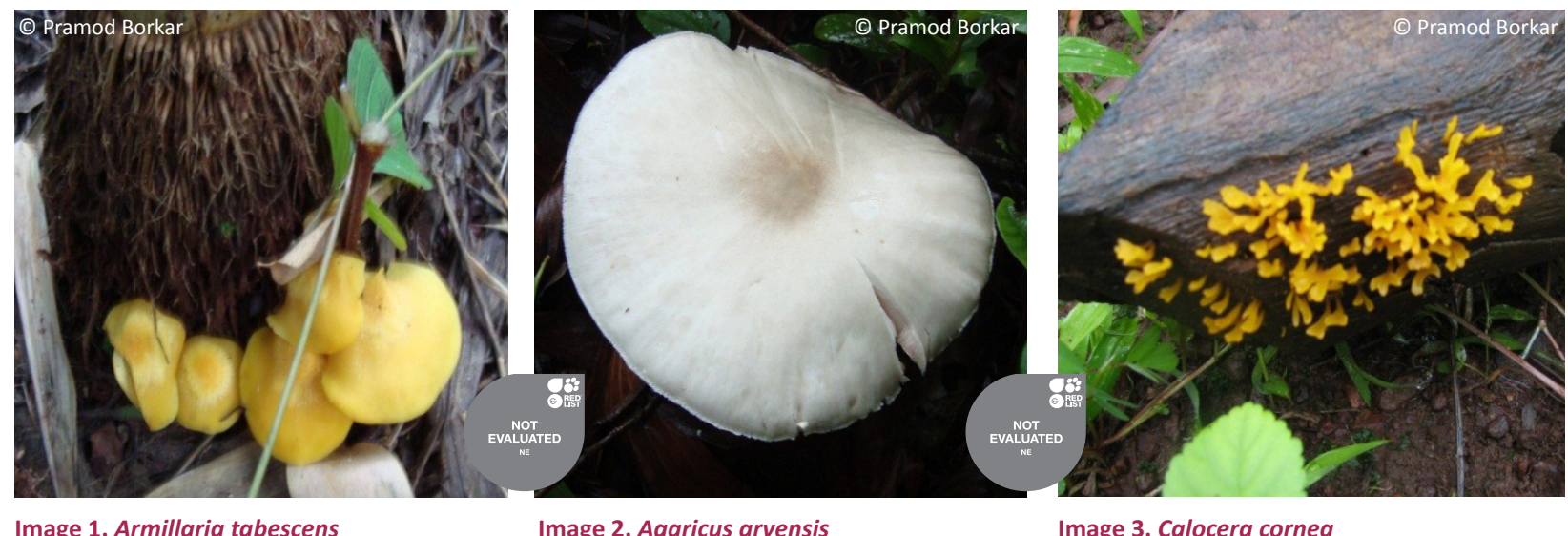

Pileus: Diameter $10 \mathrm{~cm}$, buff white with prominent central dark brown spot and conspicuous brown to black squamules, granulose, convex with entire margin.

Stipe: Buff white, fibrous, equal throughout the length but with abruptly bulbous base measuring 7-8 $\mathrm{cm}$ in length and $3 \mathrm{~cm}$ in width.

Lamellae: pink, free, crowded. Spore print pinkish. Annulus: membranous, veil present initially rupturing at maturity andvolva absent. Mushroom with strong odour of turpentine (phenolic compounds).

Microscopic features: Spores brown, ellipsoid $5 \times 2.5 \mu \mathrm{m}$ ( L X B). Basidia measuring $15 \times 5 \mu \mathrm{m}$, cystidia not observed.

\section{Agaricus trisulphuratus Berk. (Agaricaceae)}

Habitat: Growing in soil, solitary. Also found on the roots of members of Palmaceae (coconut and arecanut).

Pileus: Diameter 2.5-3 cm, bright orange, fibrillose (flocculose), with imbricate, appressed squamules, convex, with crenate margin.

Stipe: Concolorous with pileus, equal, hollow measuring $4-5.5 \mathrm{~cm}$ in length and $2.5-3 \mathrm{~mm}$ in width.

Lamellae: Pale pinkish, crowded, freely attached. Spore print: dark brown. Annulus, present; volva, absent.

Microscopic features: Spores dark brown, oval to ellipsoid, measuring $5 \times 2.5 \mu \mathrm{m}$. Basidia: $12.5 \times 2.5 \mu \mathrm{m}$. Cystidia not observed.

\section{Calocera cornea (Batsch.) Fr. (Decrymycetaceae) (Image} 3)

Habitat: Lignicolous on dead, decaying bark less wood logs. Caespitose, gregarious

Fruit body: Small, bright yellow coloured fruit bodies, forked in the upright top portion. About 2-3 or sometimes up to $8 \mathrm{~cm}$ in length. Gelatinous but firm.

Microscopic features: Spores hyaline or white, oval to cylindrical measured $5 \times 2.5 \mu \mathrm{m}$. Basidia measured $30 \times 5 \mu \mathrm{m}$ while cystidia not observed.

\section{Clitocybe sp. Fr. (Tricholomataceae)}

Habitat: On decaying wood logs.

Pileus: Infundibuliform, granulose to fibrillose scaly creamy measured $4.5-6.1 \mathrm{~cm}$ in diameter with undulate margin.

Stipe: Thin, papery with lemon smell, cylindrical and concolorous with pileus, fleshy with $3.2 \mathrm{~cm}$ in length.

Lamellae: Crowded, decurrent and concolorous with pileus. Spore print was creamy white annulus and volva not observed.

Microscopic Features: Spores hyaline cylidrical to allantoid; measuring $8.13 \times 2.5 \mu \mathrm{m}$ basidia measured $7.5 \times 1.25 \mu \mathrm{m}$ while, cystidia not observed.

\section{Craterellus tubaeformis (Fr.) Quel. (Cantharellaceae) (Image 4a,b)}

Habitat: In plant debris of perennials.

Pileus:1.5-2.5cm in diameter, yellow with brown to black tiny spots, fibrillose surface umblicate to convex with crenate margin.

Stipe: Equal when young, broadening apically in age, twisted and slightly flattened at the base; Yellowishgreen, hollow measured $7-9 \mathrm{~cm}$ in length and $1.5 \mathrm{~mm}$ in width.

Lamellae: Distant, adnexed to decurrent, creamy. Spore print was white; annulus and volva not observed.

Microscopic features: Spores hyaline, globose to sub-globous, measuring $3.75 \times 2.5 \mu \mathrm{m}$. Basidia measured $20 \times 2.5 \mu \mathrm{m}$ while cystidia not observed.

Daldinia concentrica (Bolton) Ces. \& De Not. (Xylariaceae) (Ascomycota)

Habitat: Gregarious on dead wood. 


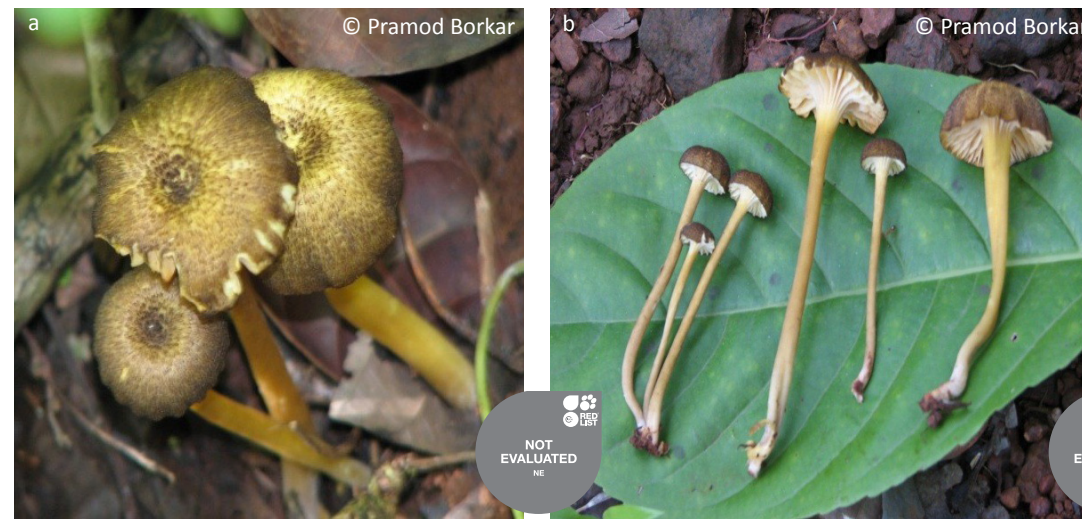

Image 4a,b. Craterellus tubaeformis

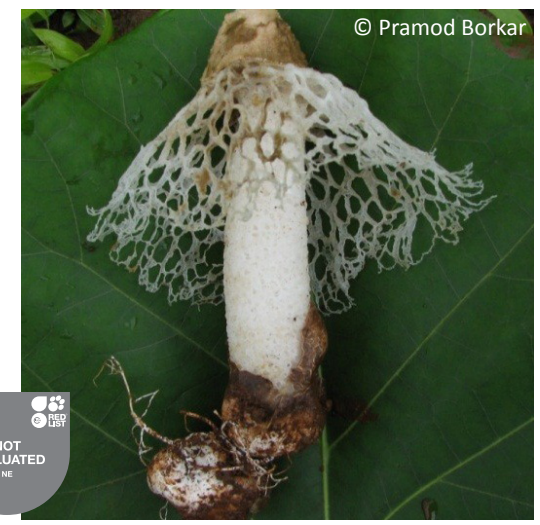

Image 5. Dictyophora duplicata
Fruit body: Pale violet to light purple colored, nearly spherical, tuber like, hard. Surface smooth on upper side, rough and tanned black on underside. About $7 \mathrm{~cm}$ in diameter; black, concentric, zonate rings in transverse section. Spore print was black.

Microscopic features: Spores amber in colour, subglobose and measured $5 \times 2.5 \mu \mathrm{m}$.

\section{Dictyophora duplicata (Bosc.) E. Fish (Phallaceae) (Image 5)}

Fruit body: Fruit body developing from a white egg. Head, dark brown, bell shaped, $2.5-3 \mathrm{~cm}$. Attached to the hollow stem at centre by an indusium (skirt like membranous outer growth) resembling a net. Indusium, 4.5-6 cm, white initially, turning brown in age. Stipe, white hollow, 15-20 cm long, composed of sponge like tissues. After emergence of fruit body, the egg portion remains attached at the stipe base as volva. Flies are attracted due to the strong unpleasant odour of the fruiting body.

Microscopic features: Spores hyaline, ellipsoid to cylindrical and measured $2.5 \times 1.25 \mu \mathrm{m}$.

\section{Entoloma roseoflavum Noordeloose. (Entolomaceae) (Image 6)}

Habitat: Roots of perennial plants.

Pileus: 3-4 cm in diameter, creamy white, glabrous, depressed with entire to undulate margin.

Stipe: Equal to tapered, concolorous with the cap, hollow; $3-5 \mathrm{~cm}$ in length and $1 \mathrm{~cm}$ in width.

Lamellae: Crowded, free, concolorous with pileus; spore print was pinkish-brown. Annulus and volva not observed.

Microscopic features: Spores hyaline, angular, mostly pentagonal measuring $7.5 \mu \mathrm{m}$; basidia measured $20 \times 7.5$ $\mu \mathrm{m}$ while cystidia measured $25 \times 11.25 \mu \mathrm{m}$.

\section{Ganoderma lucidum (Curtis) P. Karst. (Ganodermataceae) (Image 7)}

Habitat: Growing on decaying wood logs of perennials like mango, areca nut etc.

Pileus: $25-27 \mathrm{~cm}$ in diameter or more, white initially, then forming zonate rings of reddish-brown to dark brown, glabrous initially then becoming rough and corky, depressed, hemispherical, fan shaped brackets with undulate margin.

Stipe: Present in young fruit bodies growing in association with plant roots. Absent on stems. White initially, shiny red turning brown with age, hard, corky; 4-5 cm in length and $1.5-2 \mathrm{~cm}$ in width when present.

Lamellae: Absent. Spores released through poroid lower surface. Spore print was light brown to pink. Annulus and volva were absent.

Microscopic features: Spores rusty brown, oval, truncated, double walled, with a row of pillars between the walls and measured $7.5 \times 6.25 \mu \mathrm{m}$. Basidia and cystidia not observed.

\section{Hygrocybe conica (Schaeff.) P. Kumm. (Hygrophoraceae) (Image 8)}

Habitat: Plant debris of perennials.

Pileus: Red to maroon, $5 \mathrm{~cm}$ in diameter, striate to plicate with small dark spots; conical splitting at maturity, margins eroded with striations at rim of pileus.

Stipe: Cylindrical initially yellow then becoming concolorous with pileus with longitudinal groves along the total length. Fibrous with hollow centre measured $4-6 \mathrm{~cm}$ in length and $1.8-2.1 \mathrm{~cm}$ in width.

Lamellae: Subdistant, adnexed, creamy initially black at maturity. Spore print was white. Annulus and volva not observed.

Microscopic features: Spores hyaline, globose, apiculate, measuring $5.63 \mu \mathrm{m}$. Basidia measured $10 \times 5$ 


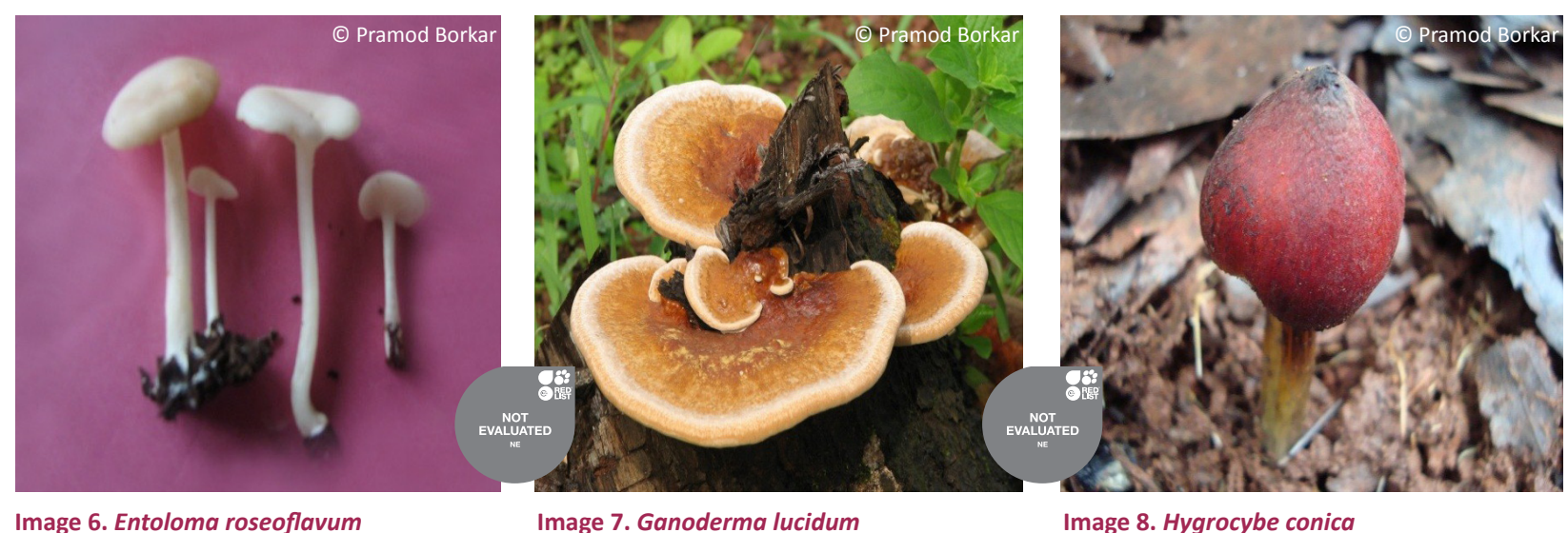

$\mu \mathrm{m}$ while cystidia not observed.

\section{Hygrocybe miniata (Fr.) P. Kumm. (Hygrophoraceae) (Image 9a,b)}

Habitat: Decaying plant litter of perennials. Solitary or cespitose, gregarious.

Pileus: $1.5-3.5 \mathrm{~cm}$ indiameter, scarlet, shiny; glabrous, umblicate with depressed centre, remaining surface plane with denticulate margin.

Stipe: Equal, yellow, hollow measured $3.5-4 \mathrm{~cm}$ in length and 2-3 $\mathrm{mm}$ in width.

Lamellae: Distant adnate and yellowish to creamy. Spore print was white. Annulus and volva not observed.

Microscopic features: Spores hyaline, globose, measuring $8.75 \mu \mathrm{m}$. Basidia measured $42.5 \times 5 \mu \mathrm{m}$ and cystidia not observed.

\section{Lepiota spp. (Agaricaceae) (Image 10)}

Habitat: Plant debris. Solitary or gregarious in pastures.

Pileus: $13-15 \mathrm{~cm}$ in diameter, white to buff, with prominent brown spot in centre, Squarrose with distant squamules all over the surface; hemispherical, becoming convex to planoconvex in age, slightly umbonate, eroded margins with remnants of veil.

Stipe: Equal, concolorous with pileus, fibrous, more than $30 \mathrm{~cm}$ in length and $2.5-3.5 \mathrm{~cm}$ in width.

Lamellae: Crowded free and creamy white in colour. Spore print was white. Annulus was present, covering the gills completely, then tearing off and persisting like a frill at maturity and volva absent.

Microscopic features: Spores hyaline, ellipsoid to oval, thick walled measured $5 \times 3.75 \mu \mathrm{m}$; basidia measured $5 \times 2.5 \mu \mathrm{m}$ while cystidia measured 8-10x4.5 $\mu \mathrm{m}$.

\section{Lepista nuda (Bull.) Cooke (Tricholomataceae) (Image 11)}

Habitat: Growing on coconut roots, soil in banana plantation.

Pileus: Violet, and shiny when young discoloured gradually and $5-5.5 \mathrm{~cm}$ in diameter. Glabrous, umblicate with entire to undulate margin.

Stipe: Cylindrical, concolorous with pileus, fleshy $4.5-5.5 \mathrm{~cm}$ in length and $2-2.5 \mathrm{~cm}$ in width.

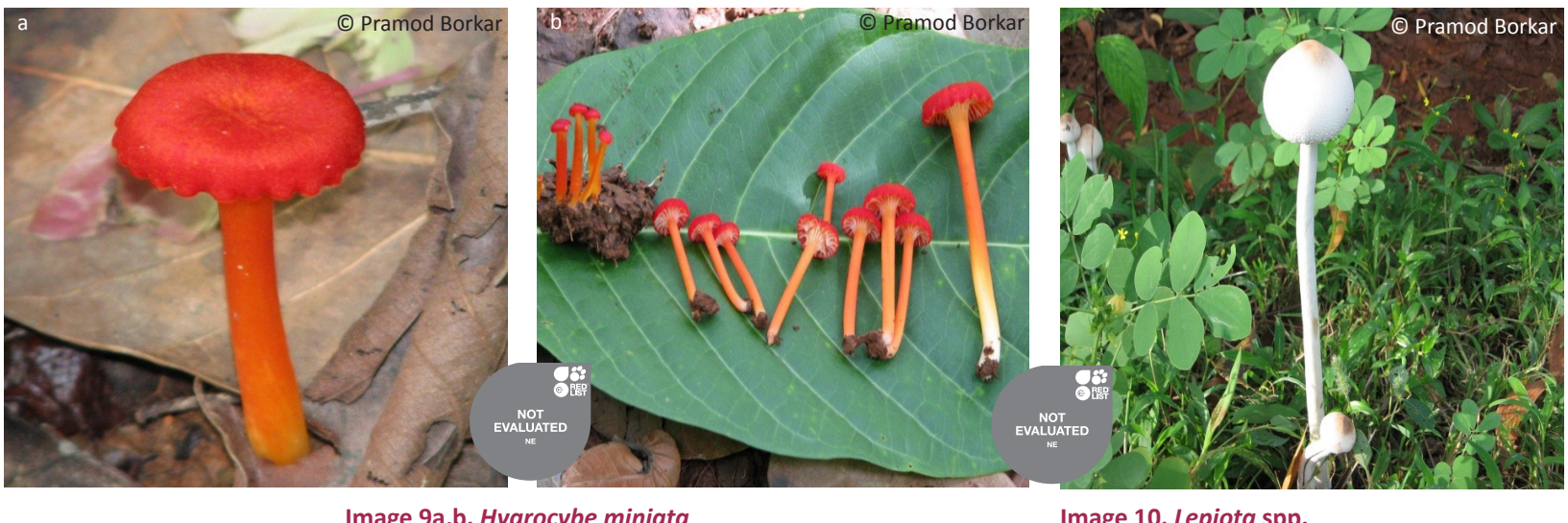




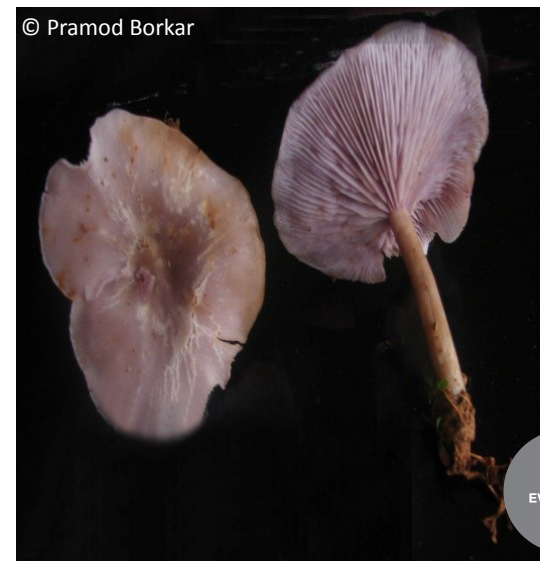

Image 11. Lepista nuda

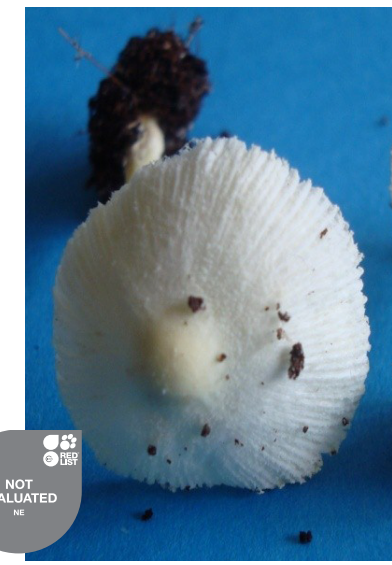

Image 12. Leucocoprinus brinbaumi

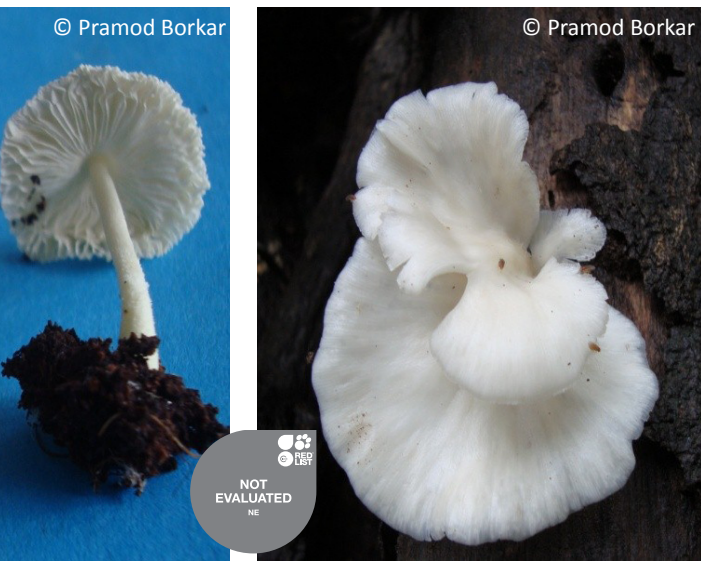

Image 13. Pleurotus ostreatus
Lamellae: Crowded, adnexed to decurrent and violet. Spore print pinkish; annulus and volva absent.

Microscopic features: Spores hyaline, globose to ellipsoid measured $5 \times 2.5 \mu \mathrm{m}$; basidia measured $23.75 \times 2.5 \mu \mathrm{m}$ while cystidia not observed.

\section{Leucocoprinus brinbaumii (Corda) Singer (Agaricaceae) (Image 12)}

Habitat: Growing in coco peat.

Pileus: Lemon yellow, 3-4 cm in diameter, fibrillose, striate to plicate, conic, with a blunt umbo becoming convex in age, with a crenate, striate to sulcate margin.

Stipe: Concolorous with pileus, equal, slightly broad at the base, hollow, 3-4 cm in length and 1-1.5 $\mathrm{mm}$ in width.

Lamellae: Concolorous with pileus, free. Spore print white. Annulus present, moving freely all along the stipe length and volva absent.

Microscopic features: Spores hyaline, ellipsoid 5x2.5 $\mu \mathrm{m}$. Basidia and cystidia not observed

\section{Macrolepiota procera (Scop.) Singer (Agaricaceae)}

Habitat: Solitary, in woods.

Pileus: Fleshy, buff to light brown, $13.5 \mathrm{~cm}$ in diameter, squarrose with dark brown shaggy scales, campanulate becoming convex in age with rimose margin.

Stipe: Light brown with prominent brown scales, cylindrical, fibrous, hollow measuring $16.5-18 \mathrm{~cm}$ in length and $1.5-1.8 \mathrm{~cm}$ in width.

Lamellae: White initially becoming dirty yellow at maturity, close, free. Spore print white. Annulus moving freely along the stipe and volva absent.

Microscopic features: Spores hyaline, broadly ellipsoid to oval, apiculate measured $9.25 \times 5 \mu \mathrm{m}$, basidia admeasuring $17.5 \times 2.5 \mu \mathrm{m}$ while cystidia measured
$26.25 \times 10 \mu \mathrm{m}$.

\section{Marasmiellus ramealis Bull. Fr. (Marasmiaceae)}

Habitat: Gregarious on dead, decaying coconut stump.

Pileus: White turning dirty light brown with age, 3-4 $\mathrm{cm}$ in diameter, glabrous to membranous, convex to umblicate with undulating margin.

Stipe: Equal, concolorous with cap, hollow measuring $1.5-2 \mathrm{~cm}$ in length and $0.5 \mathrm{~mm}$ in width.

Lamellae: Distant, adnate and white in colour. Spore Print was white. Annulus and volva not observed.

Microscopic features: Spores hyaline, ellipsoid to cylindrical, measuring $12.5 \times 5.5 \mu \mathrm{m}$. Basidia measured $27.5 \times 2.5 \mu \mathrm{m}$ while cystidia not observed.

\section{Marasmius haematocephalus f. haematocephalus (Mont.) Fr. (Marasmiaceae)}

Habitat: Hidden in grass, gregarious.

Pileus: Reddish-brown to maroon, 3-4 cm in diameter, striate to plicate, convex with crenulate margin.

Stipe: Filiform, hollow, more or less equal, frequently undulate; the base slightly swollen, dark coloured than the pileus, hard, fibrous measured $4.2 \mathrm{~cm}$ in length and 2-3 $\mathrm{mm}$ in width.

Lamellae: Distant, adnexed and creamy, purplish in colour. Spore print was white, annulus and volva absent.

Microscopic features: Spores hyaline, spherical to globose, measuring $11.25 \mu \mathrm{m}$. Basidia measured $18.75 \times 2.50 \mu \mathrm{m}$ while cystidia measured $20 \times 5 \mu \mathrm{m}$.

\section{Pisolithus tinctorius (Fr.) Pilat. (Sclerodermataceae)}

Habitat: Growing on leaf litter of Acacia mangium plantation and forming mycorrhizal association with Acacia roots. 


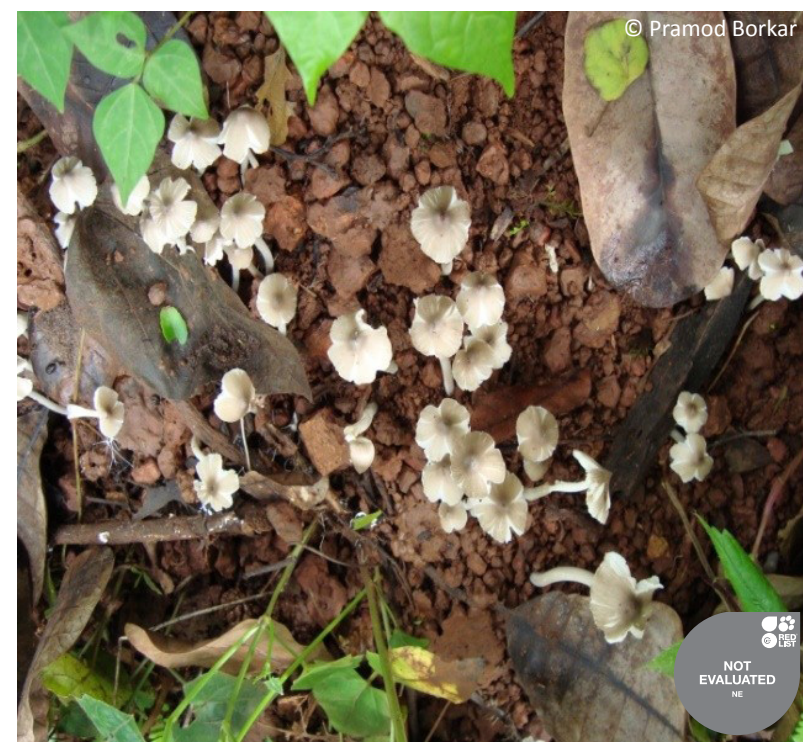

Image 14. Termitomycs clypeatus

Fruit body: Ball shaped, $20 \mathrm{~cm}$ wide. Peridium whitish to yellowish-brown, fragile, thin, smooth exposing cinnamon coloured spore mass on rupturing. Stem about, 2-3 cm. Gleba composed of white to yellowish brown cavities developing in dark brown to black gelatinous matrix.

Microscopic features: Spores hyaline, spherical to circular and measured 5.0 $\mathrm{\mu m}$

Pleurotus ostreatus (Jack.) P. Kumm., Family Pleurotaceae (Image 13)

Habitat: On decaying wood logs, dead cactus.

Pileus: Beige white, $5-7 \mathrm{~cm}$ in diameter, glabrous and depressed; typical oyster shape with undulate margin, basidioma dimidiate.

Stipe: Rudimentary.

Lamellae: Concolorous with pileus, close, decurrent. Spore print was white, annulus and volva not observed.

Microscopic features: Spores hyaline, subglobose to ellipsoid, measured $5 \times 2.5 \mu \mathrm{m}$. Basidia measured $18.75 \times 2.5 \mu \mathrm{m}$, cystidia not observed.

\section{Pleurotus pulmonarius(Fr.) Quel. Champ. (Pleurotaceae)}

Habitat: Lignicolous, on dead wood.

Pileus: Light brown, $3.5-4.5 \mathrm{~cm}$ in diameter, glabrous, convex, becoming depressed (typical oyster shaped) in age with entire margin.

Stipe: Equal, central, white. Fleshy $2.5-2.7 \mathrm{~cm}$ in length and $2 \mathrm{~mm}$ in width.

Lamellae: close decurrent, white. Spore print was white. Annulus and volva not observed.
Microscopic features: Spores hyaline, ellipsoid to cylindrical measured $7 \times 2.5 \mu \mathrm{m}$. Basidia measured $20 \times 5 \mu \mathrm{m}$, cystidia measured $25 \times 5 \mu \mathrm{m}$.

\section{Pluteus cervinus (Schaeff.) P. Kumm. (Plutaceae)}

Habitat: Soil.

Pileus: Dark brown to grey brown, $7.5 \mathrm{~cm}$ in diameter; surface glabrous initially, striate in age; umblicate with undulating margin.

Stipe: Bulbous and radicating below soil level, brown fleshy measuring $16.1 \mathrm{~cm}$ in length and $3-3.5 \mathrm{~cm}$ in width.

Lamellae: Close, free and white. Spore print was white. Annulus and volva not observed.

Microscopic features: Spores hyaline globose to sub-globose, apiculate and measured $12.5 \mu \mathrm{m}$. Basidia measured $27.5 \times 10 \mu \mathrm{m}$ while cystidia measured $20 \times 12.5$ $\mu \mathrm{m}$.

\section{Termitomycs clypeatus R. Heim (Lyophyllaceae) (Image 14)}

Habitat: In soil, gregarious.

Pileus: $3.5-5.7 \mathrm{~cm}$ in diameter, greyish to brown, conical with spiniform perforatorium, splitting at the margins with age.

Stipe: long, equal, concolorous with pileus, hollow, $12-15 \mathrm{~cm}$ in length and $2-3 \mathrm{~cm}$ wide. Lamellae, sub distant, free, light brown with brown spore print.

Microscopic features: Basidia measured $14 \times 2.5 \mu \mathrm{m}$, while cystidia were not observed. Basidiospores were hyaline, cylindrical measuring $7.5 \times 2.5 \mu \mathrm{m}$.

\section{Termitomyces heimii Natarajan (Lyophyllaceae) (Image} 15)

Habitat: Gregarious, cespitose on a termitorium soil.

Pileus: $7 \mathrm{~cm}$ in diameter, white, glabrous, convex to planoconvex with eroded margin.

Stipe: White equal and fleshy measuring $18 \mathrm{~cm}$ in length and $2 \mathrm{~cm}$ in width. Lamellae, white, crowded and free. Spore print pink, with a brownish tinge. Annulus present, volva absent.

Microscopic features: Spores hyaline, ellipsoid, thin walled measuring $7.50 \times 5 \mu \mathrm{m}$. Basidia measured $15 \times 3.75$ $\mu \mathrm{m}$ and cystidia $22.5 \times 7.50 \mu \mathrm{m}$.

\section{Termitomyces longiradicatus Sathe \& Daniel (Lyophyllaceae) (Image 16a,b) \\ Habitat: In soil Solitary or gregarious. \\ Pileus: $6 \mathrm{~cm}$ in diameter white in colour Surface granulose, campanulate in shape when young becoming planoconvex at maturity. Perforatorium mammiform,}




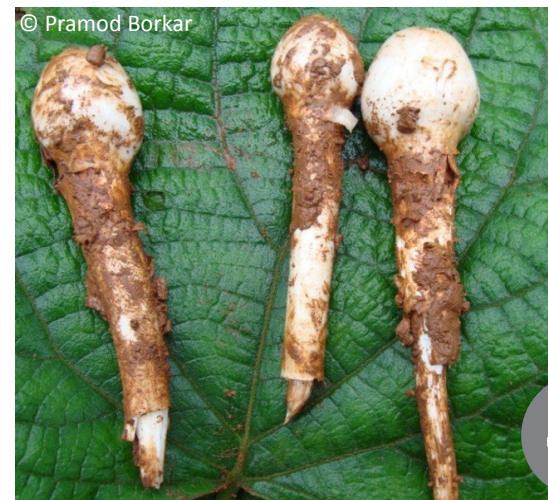

Image 15. Termitomyces heimi

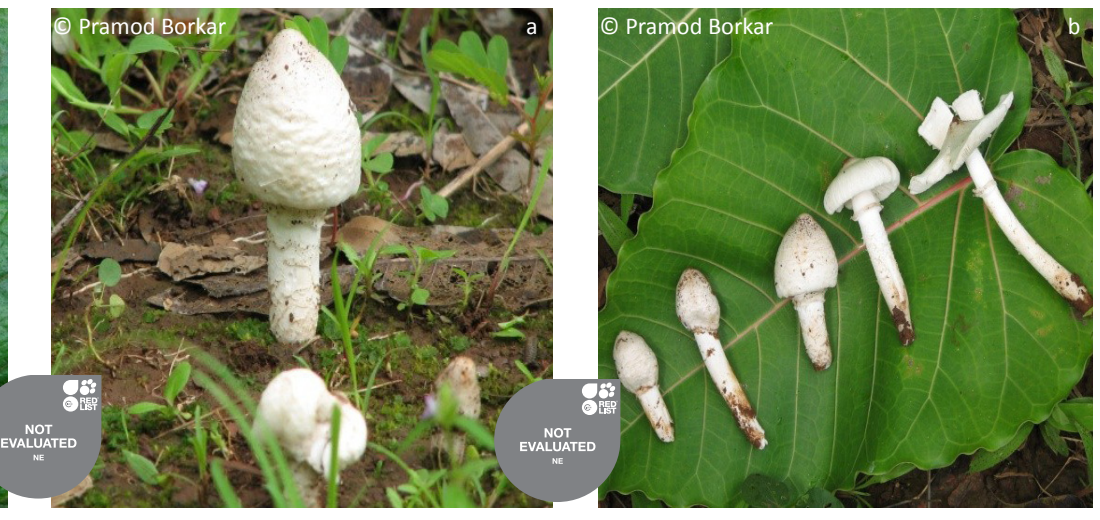

Image 16a,b. Termitomyces longiradicatus margin crenulated, splitting at maturity.

Stipe: White, fibrous Equal above ground; pseudorrhiza long below soil level, $19-20 \mathrm{~cm}$ in length $3 \mathrm{~cm}$ above ground and more than $16 \mathrm{~cm}$ below ground and $3.5 \mathrm{~cm}$ in width.

Lamellae: white, crowded with free attachment. Spore print brownish to pink. Annulus present and volva not observed.

Microscopic features: Spores hyaline, sub-globose, thin walled measuring $5 \times 3.75 \mu \mathrm{m}$. Basidia measured $12.5 \times 5 \mu \mathrm{m}$ cystidia $17.5 \times 5 \mu \mathrm{m}$.

Termitomyces microcarpus (Berk. \& Broome) R. Heim (Lyophyllaceae) (Image 17)

Habitat: On decaying plant litter in soil, gregarious.

Pileus: $2 \mathrm{~cm}$ in diameter, white, glabrous initially convex in shape becoming planocovex in age. Margins eroded.

Stipe: Concolorous with pileus, equal, hollow measuring $4.3-5.1 \mathrm{~cm}$ in length and $2 \mathrm{~mm}$ in width.

Lamellae: Concolorous with pileus, sub-distant and free, spore print pink. Annulus and volva not observed.

Microscopic features: The basidia measured $15 \times 5$ $\mu \mathrm{m}$ and the measurement of cystidia was $25 \times 6.25$ $\mu \mathrm{m}$, annulus and volva absent, basidiospores, hyaline, globose or reniform measuring $5 \times 2.5 \mu \mathrm{m}$.

\section{Termitomyces umkowaani (Cooke \& Massee) (Lyophyllaceae) (Image 18)}

Habitat: In soil, solitary.

Pileus: $7 \mathrm{~cm}$ in diameter, light brown, perforatorium spiniform. Surface, glabrous, shiny, due to oily layer on whole surface. Campanulate to conical in shape which becomes convex in age with crenate margins.

Stipe: Radicate in shape, $7.5 \mathrm{~cm}$ in length and $4 \mathrm{~cm}$ in width, swollen near the base white and fleshy. Pseudorrhiza, dark brown, radicating below the ground.
Lamellae, crowded white and freely attached. Spore print pink. Annulus and volva absent.

Microscopic features: Spores light brown, globose to oval, thin walled with an apical pore, measuring $7.5 \times 5 \mu \mathrm{m}$. Basidia $22.5 \times 5 \mu \mathrm{m}$ and cystidia $20.75 \times 9.25$ $\mu \mathrm{m}$.

\section{Tremella fuciformis Berk. (Tremellaceae) (Image 19)}

Habitat: Gregarious on wild dead wood of mango, acacia.

Fruit body: Fruit body composed of gelatinous, translucent whitish, firm, graceful lobes $1-1.5 \mathrm{~cm}$ wide, $3.5-5 \mathrm{~cm}$ in length. Each lobe dichotomously branched in apical region. Surface smooth, shiny.

Microscopic features: Spores hyaline, spherical to globose measured $5.75 \mu \mathrm{m}$ while basidia cystidia not observed.

\section{DISCUSSION}

Forays conducted in different habitats of Konkan region of Maharashtra during monsoon seasons of 2008, 2009, 2010, 2011 and 2012 revealed the repeated occurrence of 30 macrofungi in the region. These macrofungi were identified on the basis of their morphological characters described by earlier scientists.

Kuo (2004) has described Armillaria tabescens whereas; Gerault (2005) has considered A. tabescens synonymous to Clitocyb etabescenes. Burdsall \& Volk (1993) mentioned that in $A$. tabescens the annulus is lacking and the mushroom occurs in caespitose clusters. Tsykun et al. (2010) have described morphology of $A$. tabescens. On comparing the morphological description of the collected specimen with the description of previous workers the mushroom was identified as $A$. tabescens. 


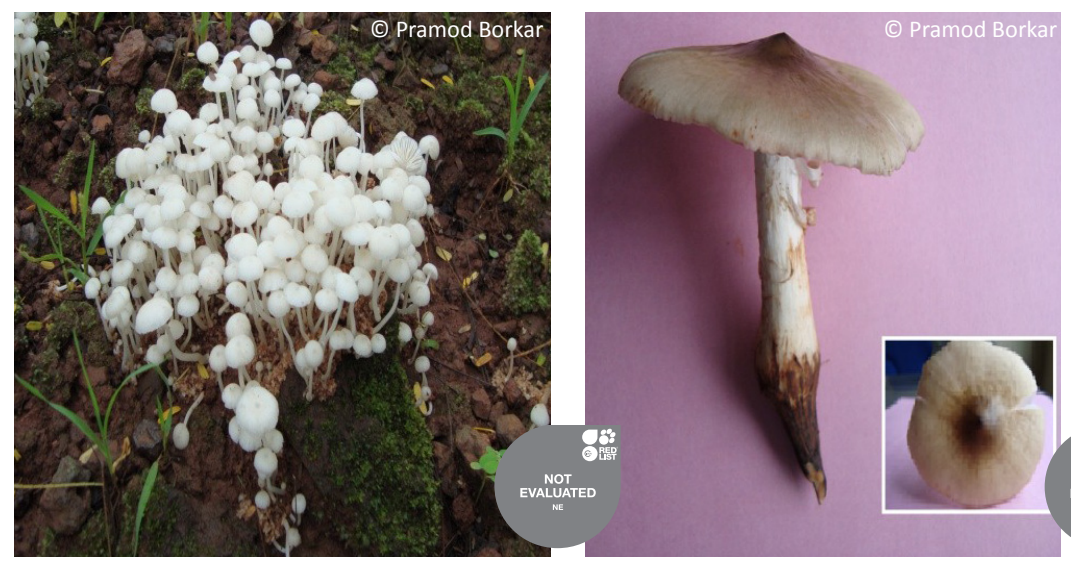

Image 17. Termitomyces microcarpus

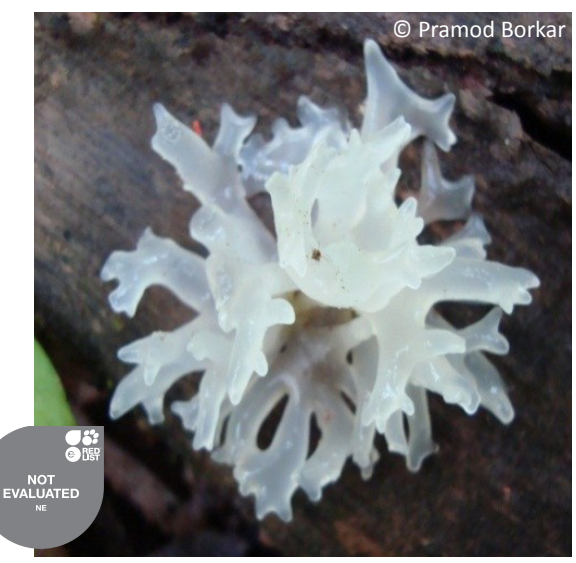

Image 19. Tremella fuciformis
The family Agaricaceae is the largest mushroom family with most of the members in the genus Agaricus. Many Indian mycologists have reported different species of this genus from different states of the country (Pegler 1977; Sathe \& Rahalkar 1978; Sathe \& Deshpande 1979; Sathe 1979; Sathe \& Kulkarni 1987; Saini et al. 1988; Nag et al. 1991; Devi 1995; Lakhanpal 1995; Saini \& Atri 1995; Verma et al. 1995). Patil et al. (1995) reported that, 41 species of this genus were recorded from Maharashtra. Purkayastha \& Chandra (1976) described four species of Agaricus viz.: A. arvensis, A. campestris, A. sylvaticus, and $A$. trisulphuratus from West Bengal. The members of the genus recorded from Rajasthan include, $A$. abruptus, A. arvensis, A. campestris, A. bisporus, A. bitorquis, $A$. placomyces, A. silvaticus and A. silvicola (Doshi \& Sharma 1997). Morphological characters of the three species of this genus collected during the present research are discussed here. As per Nair (1990), A. arvensis has subglobose, silky pileus with velar remains at margin. The pileus flattens in age. The gills are crowded, free, white when young turning blackish-brown with age. Stipe is cylindrical to club-shaped, thick, white, smooth, and stout with a large annulus. The description was matched as given on the website of Mycoweb (www.mycoweb. com) and by Kuo (2007). The second mushroom belonging to the genus Agaricus and collected from Konkan was $A$. placomyces. This mushroom was earlier reported from Kerala, northwestern Himalaya and Rajasthan (Devi 1995; Lakhanpal 1995; Doshi \& Sharma 1997) and Kuo (2007). The morphological characters of the collected specimen matched with those reported by earlier workers. Phonolic odor of the fruit body was the most striking character. The collected specimen was therefore, identified as $A$. placomyces. The morphological characters of $A$. trisulphuratus were also in conformity with those reported by earlier workers
(Saini et al. 1991; Kumar \& Sharma 2009).

The macrofungus Calocera cornea was reported from India by Verma et al. (1995) from northeastern Hills. Recently, it has been reported from Coromandel Coast of Tamil Nadu by Mani \& Kumerasen (2009). As per the description given by Kuo (2008), the fruit body is cylindrical with rounded to sharpened tips occasionally shallowly forked near the tip. Orange to yellow. In the current study the specimen was collected from bark less stem of perennial plant. The fruit body was forked, bright yellow coloured and gelatinous. Gibson (2007) in his key to club shaped fungi in Pacific North West (South Vancouver Island, Canada) has described the sporocarp of this mushroom as cylindrical forked structure fruiting on bark less hard wood. The morphological features of collected specimen were in concurrence with the description given by other workers.

One mushroom of the genus Clitocybe was reported by Sathe et al. (1980). Their description of the mushroom states, pileus $1-4 \mathrm{~cm}$ in diameter, apricot yellow in colour, margin wavy, and centrally depressed becoming deeply infundibuliform. The mushroom was found on dead coconut stump. These characters match with collected features of Clitocybe.

The mushroom Creterellus tubaeformis was reported by different workers under different names. In some reports it has been mentioned as Cantherellus cantharalloids. It is also reported as Merulius cantharalloides. The mushroom was always found in the decaying plant litter of trees like Terminalia elliptica and T. paniculata, in close proximity of Hygrocybe miniata. Castellano et al. (2003) reported that cystidia are absent in this fungus, spore print white to creamy white. Kuo (2008) has mentioned that this fungus is often saprobic or mycorrhizal. Growing alone or gregariously. Spore print white to buff yellowish in colour. Corner (1966), 
in his monograph of Cantharelloid fungi, described this mushroom with similar morphology under the name Canthrallus tubaeformis. The morphological features of collected mushroom are in concurrence with those reported in reviewed literature.

The genus Daldinia was monographed by Child in 1932 (Alexopoulos et al. 2004). The fruit bodies are found on dead wood (Lee 2004). The morphology of collected specimen was the same as described in reviewed literature.

Change \& Miles (2004) have reported that the pileus of Dictyophora duplicata is $2-4 \mathrm{~cm}$ long. The hymenium is attached to the surface of the pileus. Stipe is cylindrical in shape, hollow, white, with spongy texture and the skirt opens when fruit body is mature. The openings of the indusium are rounded, ellipsoidal or polyhedral. The long skirted species is $D$. indusiata and short skirted is D. duplicata. The volva is formed from the universal veil which ruptured by the emergence of the stalk and pileus. Spores are circular to ellipsoidal. Anonymous (2004) has reported that the fruit body arises from a sub-spherical to ovoid egg. Outer surface of the cap is covered with brownish, slimy mass. The fruit body has strong offensive odor (www.mycobank.org/mycologytaxo.aspx). Kuo (2011) also reported similar observations. In India, this mushroom was reported earlier by Devi (1995) and Doshi \& Sharma (1997). The morphological characters of collected specimen of Dictyophora duplicata were in total agreement with those described by previous workers.

Doshi \& Sharma (1997) reported Entoloma nidorosum from Udaipur while Sathe \& Kulkarni (1980) reported E. achrospora and E. strictus from Sawantwadi (Konkan). Most striking feature of this fungus was its angular basidiospores, mostly pentagonal measuring $7.5 \mu \mathrm{m}$. Noordeloos (2004) has described the general characteristics of the members of the genus Entoloma. He has classified the angular spores observed in different species into four categories such as isodiametrical (5 angled), heterodimetrical (6 angled), subisodiametrical (7 angled) and star shaped or cruciform. Manimohan et al. (2006) have provided a key to Entoloma species occurring in Kerala. Noordeloos \& Morozova (2010) have described E. roseofulvum. These morphological details are mostly in agreement with those of the collected specimen. Therefore, the fungus was identified as Entoloma roseoflavum.

Review of literature revealed that the genus Ganoderma has a worldwide distribution. It grows on a numerous perennials, coniferous and palmaceous hosts. Some Ganoderma species are wood rotting fungi, many are pathogenic to economically important crops causing root and stem rots. In forest ecosystem they play an important role in breakdown of lignin of woody plants. Ganoderma is the largest genus in order Apphyllophorales with more than 300 species. In 1881, Karsten established the genus with the type species G. lucidum and a number of species has been described in the genus thereafter. Different taxonomic characters were used for identification by various authors like Murill, Atkinson, Coleman, Corner, Steyaert etc. Moncalvo \& Ryvarden (1977), published a world list of Ganoderma species (Bhosle et al. 2010). Fifteen species of Ganoderma were reported from Western parts of Maharashtra by Bhosle et al. (2010), with the help of a key prepared to differentiate the species on the basis of morphological characters. Tiwari et al. (2005) has provided a taxonomic overview of Ganoderma and described nine species on 91 hosts from India. Later on they described 17 species of the genus from central India with photographs and host details (Tiwari et al. 2013). The basidiocarps were designated as laccate and stipiate for G. lucidum complex and non laccate and generally astipiate for $G$. applanatum complex. Muthelo (2009) followed Adaskaveg and Gilbertson's key considering context colour and basidiospores size to differentiate the species of Ganoderma. Bhosale et al. (2010) described G. lucidum. Muthelo (2009) stated that the context colour of G. lucidum is tan to brown. Petersen (1983) reported that Ganoderma can be recognized by the shiny orange red wax crust and presence of stipe.

Perennial trees such as Ain (Terminalia elliptica) and Kinjal (T. paniculata) are of common occurrence in all the forests of the Konkan region. In decaying plant litter of these trees, Hygrocybe miniata was repeatedly observed during the present study. The other member of this genus collected during the surveys was Hygrocybe conica. But it occurs in forests as well as in open fields. The reports of occurrence of both these members of Hygrophoraceae and their morphological features are discussed here. Doshi \& Sharma (1997) reported four species of the genus Hygrocybe, viz., $H$. eburnea, $H$. russula, $H$. sulphureus and $H$. benzoninum from Rajasthan. $H$. ceracae, $H$. indica, Hygrophorus partensis were reported from Maharashtra (Patil et al. 1995). Verma et al. (1995) also reported $H$. miniata from northeastern hills of India. The species of this genus occurring in northwestern Himalaya were, $H$. conica, $H$. miniata, $H$. psittacina and $H$. calopus (Lakhanpal 1995). Natarajan (1995) reported $H$. ceracae, $H$. chlorophena, $H$. fornicate $H$. miniata and $H$. westii from southern India while Devi (1995) reported $H$. calypraeformis, H. conicus, 
and $H$. puncia from Kerala. The morphological features of the collected macrofungi are in agreement with those described earlier. The fungus was therefore, identified as Hygrocybe miniata (Fr.) Kummer. Morphological features of the collected fungus Hygrocybe conica are in conformity with those described on authentic macrofungi websites.

A single member of the genus Lepiota was collected during present studies. Metzler \& Van (1992) mentioned that the diversity of Lepiota extends to edibility as well as morphological features. Large sized species of the genus are often robust, creamy to white with very noticeable scales or patches on cap that do not wash off. The presence of scales or patches on cap is one of the best distinguishing features. Eight species of the genus Lepiota were reported by Devi (1995). Patil et al. (1995) mentioned eleven species of the genus recorded from Maharashtra. Many other workers have reported Lepiotas from different states of the country (Natarajan 1995; Rafique \& Patel 1995; Saini \& Atri 1995; Verma et al. 1995). The morphology of the collected fungus was in concurrence with the description in earlier reports.

The pileus, lamellae and stipe of Lepista nuda were violet in colour and this was a very peculiar characteristic of this mushroom. Mirko (1975) described the morphological features of this fungus as, fruit body amethyst purple when young. Colour of cap and gills disappears with age and changes into cloudy purple or beige brown. Flesh has a pleasant smell. Purple colour of the stipe is retained for long time and this fungus was earlier reported by Sathe \& Deshpande (1980) from Panchagani, Maharashtra as Lepista nudoidea. Often slightly bulbous at the base, bluish-lilac. Flesh thick, bluish-lilac. Gills crowded, bluish-lilac (http://www. rogersmushrooms.com) or in fairy rings under a variety of hardwoods and conifers (http://www.mykoweb.com/ CAF/species/Clitocybe_nuda.htm). On the basis of comparison between the morphological characters of the collected specimen with the description in reviewed literature, the fungus is identified as Lepista nuda.

Singer (1986) recognized 13 species in genus Leucocoprinus while Wasser (1993) mentioned 18 species. According to recent literature (Kirk et al. 2008) there are 40 species in this genus. Manjula (1983) listed five species from India, Natarajan et al. (2005) listed six species, and Kumar \& Manimohan (2009) reported a new species from Kerala State. Only one species has been reported from Karnataka (Pushpa \& Purushothama 2011) with conical pileus becoming campanulate with age, membranous; surface yellow, floccose squamulose; plicate striate, with velar remains.
Members of the genus Macrolepiota are of worldwide occurrence. Like many other countries this mushroom was reported by a number of workers from India. Collected specimen of Macrolepiota is in agreement with the description reported by Nair (1990).

Tsykun et al. (2010) described Marasmius ramealis with the following characters. Conical to hemispherical when young, convex to conical later and having ochraceous yellow to brown. Lamellae with adnate to decurrent attachment; stipe; without annulas, cylindrical slightly broad at the base. The morphological features of the collected specimen are in conformity with those described Wannathes et al. (2009) and Antonin \& Buyck (2006). Five species of Marasmius including $M$. haematocephalus were reported from Maharashtra (Patil et al. 1995). On the website of Rogers mushrooms, the description of $M$. ramealis says that the cap is convex to flattened, centrally depressed, whitish pink in colour, membranous and wrinkled. Gills are distant, white to pinkish and the spore print is white. All these characters are matched with collected specimens of $M$. ramealis.

During the forays it was observed that at some locations the fruit bodies of Pisolithus tinctorius were larger than those normally observed. Sometimes these fruit bodies grow on the underground roots of Acacia plants along the roadside and during the period development, they grow out by breaking the soil surface or even the tar roads and hence locally called as bhuiphoda (land breaker). The review of literature revealed that, this fungus is in mycorrhizal association with the roots of the members of families such Fabaceae and Myrtaceae. On the basis of morphological and cultural studies and polypeptides analysis of 100 specimens, Burgess et al. (1995) described the variation in basidiome and basidiospore morphology of $P$. tinctorius isolates mycorrhizal with Eucalyptus, Pinus casuarhina and Acacia. The morphological characters of the basidiome of the collected specimen were in concurrence with those mentioned by Burgess et al. (1995) but the basidiospores were smaller in size then the four ranges mentioned by them. So also the spines on the basidiospores were not observed under 100X. This points out that the species collected in the present study was different than those studied by Burgess et al. (1995), Razzaq \& Shahzad (2004) for the first time reported occurrence $P$. tinctorius in Eucalyptus plantations in sandy soils of Karachi in summer season. The morphological description of collected fungi was in agreement with that reported by earlier workers. On this basis the fungus was identified as $P$. tinctorius. The occurrence of this fungus in Maharashtra was reported 
by Pande (1972). Recently, it was reported by Mani \& Kumaresen (2009) from Tamil Nadu, by Hedawoo (2010) from Amaravati region and by Karwa \& Rai (2010) from Melghat region of Maharashtra.

The genus Pleurotus is a vast genus comprising about 766 species (www.indexfungorum.org/names/Names. asp). The species in this genus are difficult to differentiate taxonomically because of the variability in fruit body morphology. Several species have been described under more than one name all over the world (Buchanan 2001). The morphology of three species of Pleurotus collected during the present study is discussed below. The stipe of $P$. pulmonarius is typically eccentric than lateral while in $P$. ostreatus it is more lateral than eccentric (Buchanan 2003). All the two species of Pleurotus collected during the present study were morphologically different. The basidiocarp of $P$. ostreatus was astipiate, dimidiated and nearly white. The pileus of $P$. pulmonarius was light brown with small stipe. Many workers in the country had reported different species of Pleurotus (Singh 1977; Devi 1995; Patil et al. 1995; Verma et al. 1995; Doshi \& Sharma 1997; Tanti et al. 2011). Two species of the genus Pluteus, viz., $P$. articapillus and $P$. salmoneus were reported by Sathe et al. (1980) from Maharashtra. The former was recorded in Pune while the later was observed at Castle Rock. In respect of P. articapillus, Sathe et al. (1980) reported that the mushroom is commonly known under the name $P$. cervinus all over the world. Further they have mentioned that it is an edible mushroom. Natarajan \& Raman (1980) reported Pluteus from southern India. The morphology of collected mushroom in respect of colour, shape and surface of the pileus, gill attachment, and stipe was in conformity with the description mentioned above. On the basis of morphological characters it was identified as Pluteus cervinus.

Most of the recorded species of the genus Termitomyces genus all over the world occur mainly in Asian and African countries. All the species of this genus are reported to be in symbiotic association with termites and hence the genus is named as Termitomyces. Some of the members grow on epigeous termite mounds while others grow on the termitoria formed very deep below the soil level. In case of such mushrooms the pseudorrhiza (root like structure of the mushroom fruit body) is quite long. The lateritic soils of Konkan region are conducive for growth of termites. As a result, all the dried plant litter in fruit orchards and plantations is attacked by termites. Sometimes the termites grow on the trunks of live plants. During the present investigation, five species of the genus were collected from all the four districts of the Konkan region. Several species viz., T. albuminosa $T$. cartilagineous $T$. clypeatus T. mammiformis T. microcarpus T. poonensis $T$. robustus T. eurrhizus, T. heimii, T. radicatus, T. robustus and $T$. stiatus $T$. indicus, T. rabuorii, T. microcarpus $\mathrm{f}$. santalensis, T. letestui, (Sathe et al. 1980; Nair 1990; Devi 1995; Natarajan 1995; Saini \& Atri 1995; Doshi \& Sharma 1997; Verma et al. 1995; Purkayastha \& Chandra 1985; Tanti et al. 2011) had been reported from India. Tang et al. (2005) reported that a total of 68 species of this genus have been recorded worldwide. Macromorphological characteristics of Termitomyces provide more reliable taxonomic information to delineate most of the species in the genus than micro-morphology. The micro-morphology is less informative and ambiguously used by many workers (Tibuhwa et al. 2010). In his monograph on the genus Termitomyces, Heim (1977) has given a detailed account of the species of this genus occurring all over the world. A key to the species of Termitomyces from India by Vrinda \& Pradeep (2009) includes morphological characters of sixteen previously reported species as well as a lesser known species, T. sagittiformis. According to the key, the mushroom with straw coloured to brownish pileus, pointed perforatorium, black pseudorrhiza and absence of annulus is T. umkowaani. Morphological features of the collected specimen matched with that of Sathe \& Daniel (1980). They have also mentioned that $T$. longiradicatus is closer to $T$. heimii but differs in having long radicating stipe. The fungus was therefore, identified as $T$. longiradicata. T. heimii was first described by Natarajan (1979) the morphological features of the specimen recorded in the present study are in conformity with those given by Natarajan (1979) and Sathe \& Daniel (1980). According to Vrinda \& Pradeep (2009), T. longiradicatus is a synonym of $T$. hemii. In the present study, the pileus of $T$. longiradicata was granulose and that $T$. heimii was glabrous. So also the stipe length of $T$. longiradicata was less above ground and pseudorrhiza was long. In T. hemii the stipe was $18 \mathrm{~cm}$ above the soil. Due to this difference in morphological characters of both these mushrooms, it is appropriate to consider them as separate species. T. microcarpus was reported by most of the workers in the country. Nair (1980) described this mushroom as per the key given by Vrinda \& Pradeep (2009). Kesel (2011) mentioned that, the fruit body of T. microcarpus has very small cap and the pseudorhiza is absent. Tibuhwa et al. (2010) reported that the pileus of $T$. microcarpus is white, small, stipe, white, annulus and pseudorhiza absent. Atri et al. (1995) described this fungus with $1 \mathrm{~cm}$ broad, yellowish-white pileus, 
lamellae subdistant, and spore print light orange. The morphological characters of the fungus collected during present study are in concurrence with those described by earlier workers. The fifth species of the genus Termitomyces collected from the Konkan region was $T$. clypeatus. Nair (1980), in his description of this species, mentioned that the pileus is conical at first with strongly spiniform perforatorium, expanding with age. As per Froslev (2000) the perforatorium of this mushroom is strongly spiniform. The perforatorium of $T$. clypeatus is grayish to buff brown paling towards margin, stem white pseudorhiza present, annulus absent (Tibuhwa et al. 2010). Perforatorium spiniform with grayish brown pileus (Kesel 2011). According to Wei et al. (2006) the spiniform perforatorium, smooth and non-annulate stipe surface, and pale stipe and pseudorhiza indicate that it is a collection of $T$. clypeatus. Furthermore, the microscopic characters of the type, e.g., size and form of basidiospores, basidia and cystidia, are in agreement with that of $T$. clypeatus. Hence the fungus described by Zang (1981) as Sinotermitomyces taiwanensis is $T$. clypeatus. Considering all the morphological characters described by previous workers and comparing them with the morphology of the collected specimen, this fungus was identified as T. clypeatus Heim.

Chang \& Miles (2004) described two types of fruiting bodies in Tremella fuciformis. The nut gall type has folds or lobes and the other type looks like a cock's comb. As per Kuo (2008), the fruit body is composed of graceful lobes, transparent, whitish, up to $7 \mathrm{~cm}$ across and $4 \mathrm{~cm}$ high and shiny. Anonymous (2000) described the fruit body as a basidiocarp with lobes which were forked with incised crenate margin gelatinous, firm and up to $5 \mathrm{~cm}$ in height. The spores are ellipsoid, smooth and hyaline. The basidiocarps are cespitose (www.mycobank.org). The collected mushroom was identified as T. fuciformis on comparing the characters of collected specimens with the description given by previous workers.

The present study does not include all the macrofung occurring in the region. It is just an effort to peep into the hidden treasure of these colorful and fascinating fungi.

\section{CONCLUSIONS}

Forays conducted during monsoon of 2008, 2009, 2010, 2011 and 2012 revealed the presence of 29 mushrooms belonging to different families. Among these, six species of Agaricaceae and six of Lyophyllaceae from one-third of the total collection.
The noteworthy outcome of the present study was the occurrence of five species of Termitomyces, Pleurotus pulmonarius, Lepista nuda, Tremella fuciformis, Dictyophora duplicata and Pluteus cervinus which are edible and Tremella is a medicinally important mushroom. There is a vast scope for documentation of macrofungi from this region in future.

\section{REFERENCES}

Alexopoulos, C.J., C.W. Mims \& M. Blackwell (2004). Introductory Mycology. John Wiley \& Sons. (Asia) Pte. Ltd., 808pp.

Antonin, V. \& B. Buyck (2006). Marasmius (Basidiomycota, Marasmiaceae) in Madagascar and the Mascarenes. Fungal Diversity 23: 17-50.

Atri, N.S., S.S. Saini \& G. Kaur (1995). Studies on north Indian Agarics: The Genus Termitomyces. Mushroom Research 4: 7-10.

Bhosale, S., K. Ranadive, G. Bapat, S. Garad, G. Deshpande \& J. Vaidya (2010). Taxonomy and Diversity of Ganoderma from western parts of Maharashtra (India). Mycosphere 1(3): 249-262.

Buchanan, P.K. (2003). Identification, Names and Nomenclature of Common Edible Mushrooms. Proceedings of $2^{\text {nd }}$ International Conference on Mushroom Biology and Mushroom Production, Green Books.

Burdsall H.H. Jr. \& T.J. Volk (1993). The state of taxonomy of the genus Armillaria. Macilvainea 11(1): 4-12.

Burgess T., N. Malajczuke \& B. Dell (1995). Variation in Pisolithus based on Basidiome and Basidiospore Morphology, Culture Characteristics and Analysis of Polypeptides Using 1D-SDS-PAGE. Mycological Research 99(1): 1-13.

Castellano, M.A., E. Cazares, B. Fondric \& T. Dreisbach (2003). General Technical Report, USDA, 53-58pp.

Chang, S.T. \& P.G. Miles (2004). Mushroom: Cultivation, Nutritional Value, Medicinal Effect and Environmental Impact. ( ${ }^{\text {nd }}$ edition). CRC press New York, $\mathrm{xx}+451 \mathrm{pp}$.

Corner E.J.H. (1966). A Monograph of Cantharelloid Fungi. Oxford University Press, 255pp.

Devi, B. (1995). Mushroom Flora of Kerala, pp. 277-316. In: Chadha, K.L. \& S.R. Sharma (eds.). Advances in Horticulture Vol. 13 Mushroom. Malhotra Publishing House, New Delhi.

Doshi A. \& M. Sharma (2011). Biodiversity and Coservation of Mushrooms in Rajasthan. In: Kannian, S., T. Marimuthu \& K. Lenin (eds.). Diversity and Production of Edible Mushrooms. Associated Publishing Company, India, vii+184pp.

Doshi A. \& S.S. Sharma (1997). Wild Mushrooms of Rajasthan, pp. 105-127. In: Rai, R.D., B.L. Dhar \& R.N. Verma (eds.). Advances in Mushroom Biology and Production. Mushroom Society of India, N.R.C.M., Chambaghat, Solan (HP), India.

Doshi A. \& S.S. Sharma (1990). A new mushroom Termitomyces eurhizusfrom Rajasthan. Indian Journal of Mycology and Plant Pathology 20: 279.

Doshi A., A. Trivedi \& S.S. Sharma (1994). Fleshy Fungi from Rajasthan. Abstract of Paper Presented in National Symposium on Mushroom held at Solan.

Froslev, T. (2000). http:// www.mycokey.com/burkinaFaso/ Termitomyces.html.

Gibson I., (2007). Trial Field Key to Club Shaped Fungi in Pacific North West. Pacific North West Key Council Publication.

Harsha N.S.K. \& K. Joshi (2008). Mushroom: The Vegetable of Future. http://www.nistads.res.in/indiasnt2008/t6rural/t6rur12.htm.

Hedawoo, G.B. (2010). Wild mushroom flora from Amaravati region, Maharashtra, India. Journal of Mycology and Plant Pathology 40(3): 441-444.

Heim, R. (1977). Termites et Champignons: Les Champignons 
Termitophiles $d^{\prime}$ Afrique Noire et $d^{\prime}$ Asie Meridionle. Societe Des Editions Boubee, Paris.

Karwa, A. \& M.K. Rai (2010). Hitherto Unreported Agaricus species of Central India. Nusantara Bioscience 2(3): 141-145.

Kesel, A. de (2011). Provisional Macroscopic Key to the Edible Mushrooms of Tropical Africa. MycoAfrica 4(1): 1-8.

Kirk P.M., P.F. Cannon, D.W. Minter \& J.A. Stalpers (2008). Dictionary of the Fungi (10th ed.), Wallingford, CABI p.374

Kumar, T.K.A. \& P. Manimohan (2009). The genera Leucoagaricus and Leucocoprinus (Agaricales, Basidiomycota) in Kerala State, India. Mycotaxon (108):385-428; http://dx.doi.org/10.5248/108.385

Kumar, S. \& Y.P. Sharma (2009). Macrofungi of Jammu Province (J \& K) India. Indian Journal of Forestry 32(1): 113-118.

Kuo (2004). http://www.mushroomexpert.com/armillaria_tabescens. html

Kuo (2007). http://www.mushroomexpert.com/agaricus_arvensis. html

Kuo (2008). http://www.mushroomexpert.com/phallus_duplicatus. html

Kuo (2008). http://www.mushroomexpert.com/tremella_fuciformis. htm

Kuo (2008). http://www.mushroomexpert.com/calocera_cornea.htm Kuo (2008). http://www.mushroomexpert.com/craterellus_ tubaeformis.html

Lakhanpal, T.N. (1995). Mushroom Flora of North West Himalayas, pp. 351-373. In: Chadha, K.L. \& S.R. Sharma (eds.). Advances in Horticulture, Vol. 13 - Mushroom. Malhotra Publishing House, New Delhi.

Lee, S.Y. (2004). Ultra structural description of some wood degrading fungi at light microscope and scanning electron microscopic Levels. Korean Journal of Electron Microscopy 34(4): 271-276.

Mani, S. \& V. Kumaresan (2009). Occurrence of macrofungi on the Coromandel coast of Tamil Nadu, southern India. Journal of Threatened Taxa 1(1): 54-57; http://dx.doi.org/10.11609/JoTT. o1773.54-57

Manimohan, P., M.E. Noordeloos \& A.M. Dhanya (2006). Studies on the Genus Entoloma (Basidiomycets, Agaricales) in Kerala State, India. Persoonia 19(1): 45-93.

Manjula, B. (1983). A revised list of Agaricoid and Boletoid Basidiomycetes from India and Nepal. Proceedings of Indian Academy of Science (Plant Science) 92(2): 81-213.

Metzler, G. \& M. Van (1992). Texas Mushrooms: A Field Guide. University of Texas Press.

Mirko, S. (1975). A Colour Guide to familiar Mushrooms and Fungi. Octopus Books, London, 126pp.

Muthelo, V.G. (2009). Identification of Ganoderma Species Causing Root Rot Disease of Jackaranda in Pretoria. MSc Dissertation for M.S. in Microbiology and Plant pathology, University of Pretoria.

Nair, M.C. (1990). Mushrooms, Technical Bulletin - 17. Kerala Agricultural University, 139pp.

Natarajan, K. (1995). Mushroom flora of south India (except Kerala) pp. 387-397. In: Chadha, K.L. \& S.R. Sharma (eds.). Advances in Horticulture, Vol. 13 - Mushroom. Malhotra Publishing House, New Delhi.

Natarajan, K. \& N. Raman (1980). South Indian Agaricales - IX. Sydowia 33: $225-235$

Natarajan, K. (1979). South Indian Agaricales V: Termitomyces heimii. Mycologia 71(4): 853-855

Natarajan, K., V. Kumaresan \& K. Narayanan (2005). A check list of Indian Agarics and Boletes (1984-2002). Kavaka (33): 61-128.

Noordeloos, M.E. \& O.V. Morozova (2010). New and Noteworthy Entoloma Species from the Primorsky Territory Russian Far East. Mycotaxon 112: 231-255.

Noordeloos, M.E. (2004). www.entoloma.nl./html/entinrtoeng.html Patil, B.D., S.W. Jadhav \& A.V. Sathe (1995). Mushroom flora of Maharashtra, pp. 351-373. In: Chadha, K.L. \& S.R. Sharma (eds.). Advances in Horticulture, Vol. 13 - Mushroom. Malhotra Publishing House, New Delhi.

Pegler, D.N., (1977). A Preliminary Agaric Flora of Africa. Her Majesty's
Stationary Office, London, 615pp, 131 figs

Petersen, J. E., (1983). Ganoderma in northern Europe. Denmark og. Europae Swampe 7: 1-11.

Purkayastha, R.P. \& A. Chandra (1985). Indian Edible Mushrooms Firma K. M. Private Ltd., Calcutta, India.

Pushpa, H. \& K.B. Purushothama (2011). Leucocoprinus Pat. (Agaricaceae, Agaricales, Basidiomycota) in Bangaluru, Karnataka State, India. World Applied Science Journal 14(3): 470-475.

Razzaq, A. \& S. Shahzad (2004). Pisolithus tinctorius, A New Record from Pakistan. Pakistan Journal of Botany 36 (2): 449-451.

Saini, S.S., N.S. Atri \& M.S. Bhupal (1988). North Indian Agaricales - V. Indian Phytopathology 41(4): 622-625.

Saini, S.S. \& N.S. Atri (1995). Mushroom Flora of Punjab, pp. 375-386. In: Chadha, K.L. \& S.R. Sharma (eds.). Advances in Horticulture, Vol. 13 - Mushroom. Malhotra Publishing House, New Delhi.

Saini, S.S., N.S. Atri \& A.K. Gupta (1991). Additional Studies on North West Indian Agarics. Proceedings of National Mushroom Symposium. Thiruananthapuram, Kerala, 7-12pp.

Sathe, A.V. \& S.M. Kulkarni (1987). A check list of wild edible mushrooms from south west India, pp. 411-413. In: Kaul, T.N. \& B.M. Kapur (eds.). Indian Mushroom Science, II. Regional Research laboratory, Jammu, India.

Sathe, A.V. \& S.R. Rahalkar (1978). Agaricales from South West India. Biovigyanam 3: 119-121.

Sathe, A.V. (1979). Agaricology in India - a review of work on Indian Agricales. Biovigyanam 5: 125-130.

Sathe, A.V. \& S. Deshpande (1979). Agaricales of Maharashtra, pp. 82-88. In: Chattopadhyay, S.B. \& N. Samajpati (eds.). Advances in Mycology and Plant Pathology. Oxford and IBH Publishing Co. New Delhi, India.

Sathe, A.V., S. Deshpande, S.M. Kulkarni \& J. Daniel (1980). Agaricales of South West India, Series - I. Monograph-I, Maharashtra Association for Cultivation of Science, Research Institute, Pune, India.

Sharma, S.S., A. Doshi \& A. Trivedi (1992). Edible Fleshy Fungi from Rajasthan. Mushroom Research 1: 141.

Sharma, S.S. \& A. Doshi (1990). Some Unreported Hosts of Pleurotus Species. Mushroom Information, 4pp.

Singer, R., (1986). The Agaricales in Modern Taxonomy - $4^{\text {th }}$ Edition. Sven Koeltz Scientific Books, Koenigstein, Germany, 981pp.

Singh, R.D. (1977). Edible fleshy fungi in Rajasthan. Indian J.of Mycol. \&PI. Path. 78.

Tang, B.H., T.Z. Wei \& Y.J. Yao (2005). Type Rivision of Three Termitomyces species from India. Mycotaxon 94: 93-102.

Tanti, B., L. Gurung \& G.C. Sarma (2011). Wild Edible Fungal resources Used by Ethnic Tribes of Nagaland, India. Indian Journal of Traditional Knowledge 10(3): 512-515.

Tiwari, C.K., N. Sharma \& R.K. Verma (2005). Taxonomic over view of Ganoderma lucidum with special reference to Indian species. Indian Journal of Tropical Biodiversity 13: 57-72.

Tiwari, C.K., J. Parihar, R.K. Verma \& U. Prakasham (2013). Atlas of Wood Decaying Fungi of Central India. Tropical Forest Research Institute, Jabalpur, MP, 166p.

Tibuhwa, D.D., A.K. Kivaisi \& F.S.S. Magingo (2010). Utility of macro-morphological characters used in classifying the species of termitomyces. Tanzania Journal of Science 36: 31-45.

Tsykun, T., D. Rigling, V.I. Nikolaychuk \& S. Prospero (2010). Identification and Characterization of Armillaria tabescens from the Transcarpathia of Ukraine. Science Bulletin of Uzhgorod University (Ser.Biol.) 29: 195-203.

Verma, R.N., G.B. Singh \& S.M. Singh (1995). Mushroom Flora of North Eastern Hills, pp. 329-350. Chadha, K.L. \& S.R. Sharma (eds.). Advances in Horticulture - Vol. 13, Mushroom. Malhotra Publishing House, New Delhi.

Vrinda, K.B. \& C.K. Pradeep (2009). Termitomyces sagittiformis- A lesser Known Edible Mushroom from Western Ghats. Mushroom Research 18(1): 33-36.

Wannathes, N., D.E. Desjardin, K.D. Hyde, B.A. Perry \& S. Lumyong (2009). A monograph of Marasmius (Basidiomycota) from north 
Appendix 1. List of mushrooms described

\begin{tabular}{|c|c|c|}
\hline & Species & Family \\
\hline 1 & Agaricus arvensis Schaeff & Agaricaceae \\
\hline 2 & Agaricus placomyces Peck., & Agaricaceae \\
\hline 3 & Agaricus trisulphuratus Berk., & Agaricaceae \\
\hline 4 & Armillaria tabescens (Scop.) Emel & Physalacriaceae \\
\hline 5 & Calocera cornea (Batsch.)Fr. & Decrymycetaceae \\
\hline 6 & Clitocybe spp. Fr. & Tricholomataceae. \\
\hline 7 & Craterellus tubaeformis (Fr.) Quel. & Cantharellaceae \\
\hline 8 & $\begin{array}{l}\text { Daldinia concentrica (Bolton) Ces. \& De } \\
\text { Not. }\end{array}$ & Xylariaceae \\
\hline 9 & Dictyophora duplicata. (Bosc.) E. Fish & Phallaceae \\
\hline 10 & Entoloma roseoflavum Noordeloose & Entolomaceae \\
\hline 11 & Ganoderma lucidum (Curtis.) P. Karst. & Ganodermataceae \\
\hline 12 & Hygrocybe conica (Schaeff.) P. Kumm & Hygrophoraceae \\
\hline 13 & Hygrocybe miniata (Fr.) P. Kumm & Hygrophoraceae \\
\hline 14 & Lepiota spp. (Pers.) Gray & Agaricaceae \\
\hline 15 & Lepista nuda (Bull.) Cooke & Tricholomataceae \\
\hline 16 & Leucocoprinus brinbaumii (Corda) Singer & Agaricaceae \\
\hline 17 & Macrolepiota procera (Scop.) Singer & Agaricaceae \\
\hline 18 & Marasmiellus ramealis Bull. Fr. & Marasmiaceae \\
\hline 19 & $\begin{array}{l}\text { Marasmius haematocephalus } f \text {. } \\
\text { haematocephalus (Mont.) Fr. }\end{array}$ & Marasmiaceae \\
\hline 20 & Pisolithus tinctorius (Fr.) Pilat & Sclerodermataceae \\
\hline 21 & Pleurotus ostreatus (Jack.) P. Kumm. & Pleurotaceae \\
\hline 22 & Pleurotus pulmonarius (Fr.) Quel. Champ & Pleurotaceae. \\
\hline 23 & Pluteus cervinus (Schaeff.) P. Kumm. & Plutaceae \\
\hline 24 & Termitomyces heimii Natarajan & Lyophyllaceae \\
\hline 25 & $\begin{array}{l}\text { Termitomyces longiradicatus Sathe \& } \\
\text { Daniel }\end{array}$ & Lyophyllaceae \\
\hline 26 & $\begin{array}{l}\text { Termitomyces microcarpous (Berk. \& } \\
\text { Broome) }\end{array}$ & Lyophyllaceae \\
\hline 27 & $\begin{array}{l}\text { Termitomyces umkowaani (Cooke \& } \\
\text { Massee) }\end{array}$ & Lyophyllaceae \\
\hline 28 & Termitomycs clypeatus R. Heim & Lyophyllaceae \\
\hline 29 & Tremella fuciformis Berk. & Tremellaceae \\
\hline
\end{tabular}

Thailand based on morphological and molecular (ITS sequences) Data. Fungal Diversity 37: 209-306.

Wasser, S.P. (1993). Tribes Cystodermateae and Leucocoprineae Sing. of the CIS and Baltic States. Libri Botanici 9: 1-105.

Wei, T.Z., B.H. Tang, Y.J. Yao \& D.N. Pelger (2006). A Rivision of Sinotermitomyces, an synonym of Termitomyces. Fungal Diversity 21: 225-237.

Zang, M. (1981). Sinotermitomyces, a new genus of Amanitaceae from Yunnan, China. Mycotaxon 13: 171-174.
Appendix 2. List of localities tapped with latitude and longitude.

\begin{tabular}{|c|c|c|}
\hline & Locality & Lat. and Long. \\
\hline 1 & Alore & $17^{\circ} 45^{\prime} N \& 73^{\circ} 05^{\prime} E$ \\
\hline 2 & Amboli & $17^{0} 57^{\prime} 52^{\prime \prime} \mathrm{N} 73^{\circ} 23^{\prime} 50^{\prime \prime} \mathrm{E}$ \\
\hline 3 & Anjarle & $17.85^{\circ} \mathrm{N} \& \& 73.09^{\circ} \mathrm{E}$ \\
\hline 4 & Chiplun & $15^{0} 57^{\prime} 45^{\prime \prime} \mathrm{N} \& 73^{\circ} 59^{\prime} 52^{\prime \prime} \mathrm{E}$ \\
\hline 5 & Dapoli & $17^{0} 45^{\prime} 32^{\prime \prime} N \& 73^{\circ} 11^{\prime} 8^{\prime \prime} E$ \\
\hline 6 & Devrukh & $17^{\circ} 46^{\prime} 45^{\prime \prime} N \& 73^{\circ} 7^{\prime} 9^{\prime \prime} E$ \\
\hline 7 & Enampangari & $17^{\circ} 44^{\prime} 39^{\prime \prime} \mathrm{N} \& 73^{\circ} 17^{\prime} 13^{\prime \prime} \mathrm{E}$ \\
\hline 8 & Guhagar & $16.85^{\circ} \mathrm{N} \& 73.55^{\circ} \mathrm{E}$ \\
\hline 9 & Harne & $16.00^{\circ} \mathrm{N} \& 73.75^{\circ} \mathrm{E}$ \\
\hline 10 & Jamsande & $17.187^{\circ} \mathrm{N} \& 73.553^{\circ} \mathrm{E}$ \\
\hline 11 & Kanakvali & $17^{\circ} 03^{\prime} 54^{\prime \prime} \mathrm{N} 73^{\circ} 36^{\prime} 57^{\prime \prime} \mathrm{E}$ \\
\hline 12 & Kolad & $16^{\circ} 59^{\prime} 54^{\prime \prime} \mathrm{N} \& 73^{\circ} 41^{\prime} 48^{\prime \prime} \mathrm{E}$ \\
\hline 13 & Koloshi & $17^{\circ} 0^{\prime} 41^{\prime \prime} N \& 73^{\circ} 29^{\prime} 33^{\prime \prime} E$ \\
\hline 14 & Kudal, & $17^{\circ} 43^{\prime} 58^{\prime \prime} N \& 73^{\circ} 15^{\prime} 39^{\prime \prime} \mathrm{E}$ \\
\hline 15 & Lanja & $16.00^{\circ} \mathrm{N} \& 73.687^{\circ} \mathrm{E}$ \\
\hline 16 & Mahad & $16.05^{\circ} \mathrm{N} \& 73.46^{\circ} \mathrm{E}$ \\
\hline 17 & Malvan, & $16^{\circ} 4^{\prime} 7^{\prime \prime} \mathrm{N} \& 73^{\circ} 42^{\prime} 33^{\prime \prime} \mathrm{E}$ \\
\hline 18 & Murud & $16^{\circ} 23^{\prime} 33^{\prime \prime} N \& 73^{\circ} 38^{\prime} 29^{\prime \prime} E$ \\
\hline 19 & Palghar & $16.285^{\circ} \mathrm{N} \& 73.68^{\circ} \mathrm{E}$ \\
\hline 20 & Pali & $19^{\circ} 39^{\prime} 9^{\prime \prime} \mathrm{N} \& 73^{\circ} 8^{\prime} 48^{\prime \prime} \mathrm{E}$ \\
\hline 21 & Pandur & $19.69^{\circ} \mathrm{N} \& 72.76^{\circ} \mathrm{E}$ \\
\hline 22 & Pedhambe & $16.67^{\circ} \mathrm{N} \& 73.52^{\circ} \mathrm{E}$ \\
\hline 23 & Poynad & $17.53^{\circ} \mathrm{N} \& 73.52^{\circ} \mathrm{E}$ \\
\hline 24 & Prabhanwalli & $17.47^{\circ} \mathrm{N} \& 73.2^{\circ} \mathrm{E}$ \\
\hline 25 & Rajapur & $16^{0} 51^{\prime} 32^{\prime \prime} \mathrm{N} 73^{\circ} 42^{\prime} 6^{\prime \prime} \mathrm{E}$ \\
\hline 26 & Sakharpa & $16^{0} 24^{\prime} 5^{\prime \prime} \mathrm{N} \& 73^{\circ} 25^{\prime} 51^{\prime \prime} \mathrm{E}$ \\
\hline 27 & Sangameshwar & $15.85^{\circ} \mathrm{N} \& 73.63^{\circ} \mathrm{E}$ \\
\hline 28 & Sawantwadi & $17^{0} 24^{\prime} 54.5^{\prime \prime} \mathrm{N} \& 73^{0} 32^{\prime} 19.3^{\prime \prime} \mathrm{E}$ \\
\hline 29 & Sawarde & $17.47^{\circ} \mathrm{N} \& 73.62^{\circ} \mathrm{E}$ \\
\hline 30 & Shrivardhan & $18.083^{\circ} \mathrm{N} \& 73.417^{\circ} \mathrm{E}$ \\
\hline 31 & Umberghar & $18^{\circ} 24^{\prime} 0^{\prime \prime} N \& 73^{\circ} 12^{\prime} 0^{\prime \prime} \mathrm{E}$ \\
\hline 32 & Vengurle & $18^{\circ} 40^{\prime} 58^{\prime \prime} \mathrm{N} \& 72^{\circ} 59^{\prime} 26^{\prime \prime} \mathrm{E}$ \\
\hline 33 & Wada & $18.03^{\circ} \mathrm{N} \& 73.01^{\circ} \mathrm{E}$ \\
\hline 34 & Wakavali & $17^{0} 28^{\prime} 51.1^{\prime \prime} \mathrm{N} \& 73^{0} 35^{\prime} 20.4^{\prime \prime} \mathrm{E}$ \\
\hline
\end{tabular}

